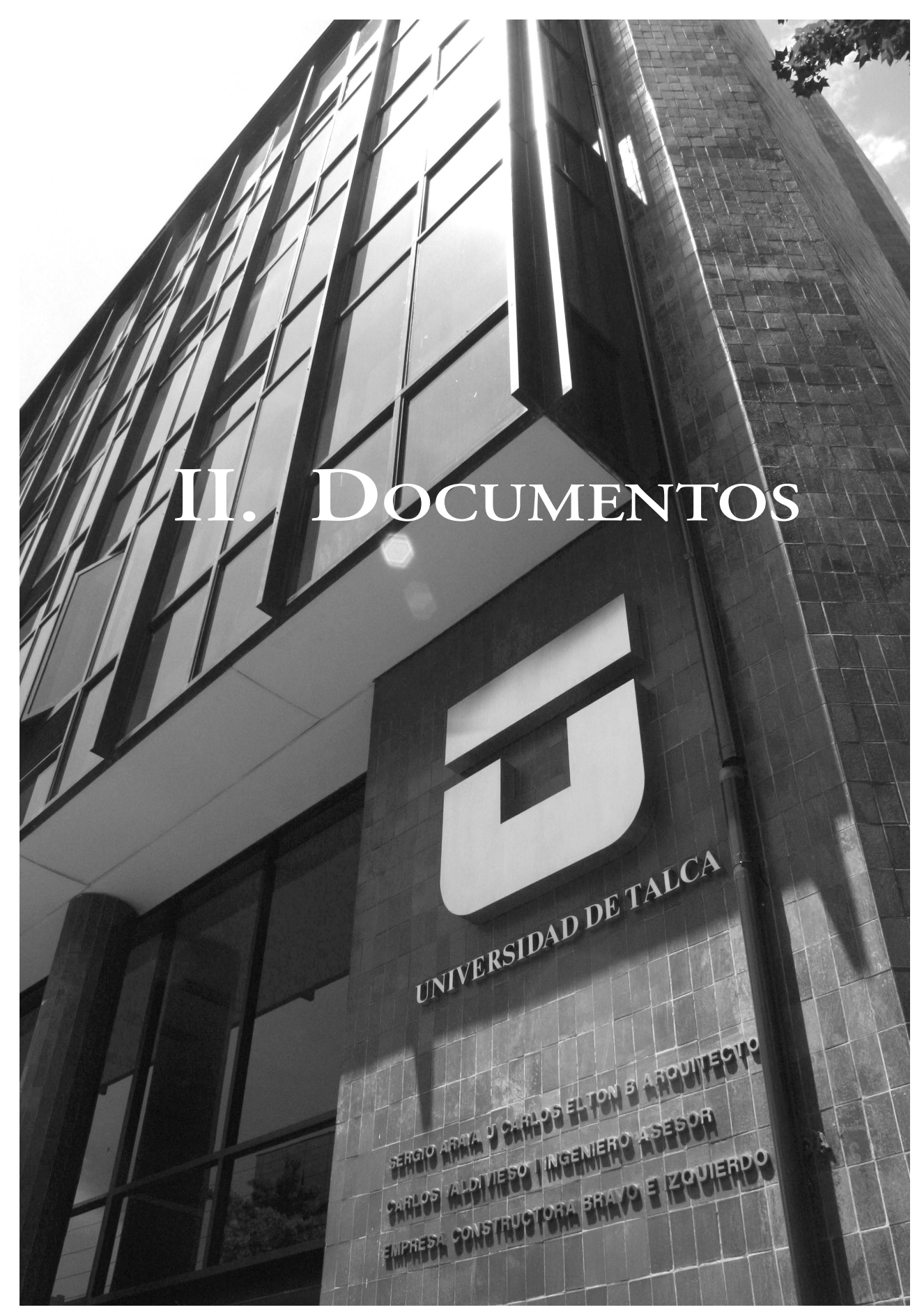



Estudios Constitucionales, Año 11, No 2, 2013, pp. 641 - 694.

ISSN 07180195

Centro de Estudios Constitucionales de Chile Universidad de Talca

"Eficacia de la sentencia interamericana y la cosa juzgada internacional: vinculación directa hacia las partes (res judicata) e indirecta hacia los Estados Parte de la Convención Americana (res interpretata)

(Sobre el cumplimiento del Caso Gelman Vs. Uruguay)"

Eduardo Ferrer Mac-Gregor

\title{
EFICACIA DE LA SENTENCIA INTERAMERICANA Y LA COSA JUZGADA INTERNACIONAL: VINCULACIÓN DIRECTA HACIA LAS PARTES (RES JUDICATA) E INDIRECTA HACIA LOS ESTADOS PARTE DE LA CONVENCIÓN AMERICANA (RES INTERPRETATA) (SOBRE EL CUMPLIMIENTO DEL CASO GELMAN VS. URUGUAY)*
}

\author{
Eduardo Ferrer Mac-Gregor** \\ Universidad Nacional Autónoma de México - México \\ ferrermac@prodigy.net.mx
}

\section{INTRODUCCIÓN: IMPORTANCIA DE LA PRESENTE RESOLUCIÓN}

\section{DE SUPERVISIÓN DE CUMPLIMIENTO DE SENTENCIA}

1. Una de las competencias más importantes que actualmente ejerce la Corte Interamericana de Derechos Humanos (en adelante "Corte IDH" o "Tribunal Interamericano") es la supervisión sobre el cumplimiento de sus propias decisiones, especialmente de las sentencias de fondo y reparaciones. Esta facultad deriva de sus atribuciones jurisdiccionales, teniendo una relación directa en la efectividad de los derechos humanos de los habitantes de nuestra región.

2. Considerando la importancia sobre esta cuestión, el Tribunal Interamericano ha implementado desde hace un lustro la realización de audiencias -públicas o privadas- de supervisión sobre el cumplimiento de sus fallos, particularmente cuando se involucran reparaciones múltiples, que implican actuaciones complejas

\footnotetext{
* El presente texto reproduce el voto razonado a la Resolución de la Corte Interamericana de Derechos Humanos de 20 de marzo de 2013, relativa a la supervisión de cumplimiento de sentencia en el Caso Gelman Vs. Uruguay. La resolución puede verse en: http://www.corteidh.or.cr/docs/supervisiones/gelman_20_03_13. doc. La Sentencia del Caso Gelman Vs. Uruguay, de 22 de febrero de 2011 puede consultarse en: http://www. corteidh.or.cr/docs/casos/articulos/seriec_221_esp1.doc. Colaboración recibida el 23 de abril y aprobada el 8 de mayo de 2013.

** Profesor de Derecho Procesal Constitucional UNAM, México.
} 
y problemáticas para los Estados. ${ }^{1}$ En las audiencias de supervisión de sentencias se analizan las posiciones del Estado y de las víctimas y sus representantes, así como se escucha el parecer de la Comisión Interamericana. Lo anterior constituye una práctica importante, en la medida en que ha permitido a la Corte IDH cumplir con la función jurisdiccional que le señala la Convención Americana y que no culmina hasta en tanto no se cumpla cabalmente y de manera íntegra con todos y cada uno de los aspectos ordenados en la sentencia respectiva. Las audiencias han contribuido a lograr la efectividad de las decisiones de la Corte IDH. No se trata de una mediación del fallo, sino de una actividad dinámica que permite contar con información reciente para que los jueces puedan realizar una adecuada valoración sobre el cumplimiento del fallo por el Estado concernido, a la vez de propiciar espacios de diálogo constructivo favoreciendo el entendimiento entre las partes y lograr el debido cumplimiento de lo decidido en la sentencia, particularmente, sobre las diversas formas de reparación para las víctimas.

3. En el presente asunto se convocó a una audiencia privada de supervisión de cumplimiento de la sentencia dictada por la Corte IDH en el Caso Gelman Vs. Uruguay (en adelante "la Sentencia"), ${ }^{2}$ la cual se llevó a cabo el 13 de febrero de 2013 durante el $98^{\circ}$ período ordinario de sesiones en la sede del propio Tribunal Interamericano.

4. La audiencia fue especialmente importante para llegar al convencimiento del cumplimiento parcial de la Sentencia, respecto de lo ordenado en los puntos Resolutivos $12,{ }^{3} 13,{ }^{4} 14^{5}$ y $17^{6}$ de la misma. Así, con la información proporcio-

\footnotetext{
1 Desde el año 2007 a la fecha se han celebrado 77 audiencias sobre supervisión de cumplimiento de sentencia. La práctica de celebrar este tipo de audiencias quedó incorporada en el artículo 69.3 del nuevo Reglamento de la Corte Interamericana de Derechos Humanos, vigente desde el $1^{\circ}$ de enero de 2010.

2 Caso Gelman Vs. Uruguay. Fondo y Reparaciones. Sentencia de 24 de febrero de 2011. Serie C No 221.

3 “12. El Estado debe realizar, en el plazo de un año, un acto público de reconocimiento de responsabilidad internacional por los hechos del presente caso, de conformidad con el párrafo 266 de la Sentencia”.

4 "13. El Estado debe colocar en un espacio del edificio del Sistema de Información de Defensa (SID) con acceso al público, en el plazo de un año, una placa con la inscripción del nombre de las víctimas y de todas las personas que estuvieron detenidas ilegalmente en dicho lugar, de conformidad con el párrafo 267 de la Sentencia”.

5 "14. El Estado debe realizar, en el plazo de seis meses, las publicaciones dispuestas en el párrafo 271 de la Sentencia”.

6 "17. El Estado debe pagar, dentro del plazo de un año, las cantidades fijadas en los párrafos 291, 293, 296 y 304 de la presente Sentencia, por concepto de indemnización por daño material e inmaterial y por el reintegro de costas y gastos, según corresponda, de conformidad con los párrafos 305 a 311 de la misma”.
} 
nada por las partes, el Tribunal Interamericano consideró en la Resolución de supervisión que nos ocupa, parcialmente cumplido el fallo debido a determinadas acciones del Estado, que consistieron en (i) la realización de un acto público de reconocimiento de responsabilidad internacional sobre los hechos del caso, conducido por el Presidente de la República y realizado en el Palacio Legislativo en presencia de las víctimas Juan Gelman y su nieta María Macarena Gelman García Iruretagoyena; (ii) la colocación de una placa en el edificio del Servicio de Información de Defensa y que funcionó como cárcel clandestina (sede actualmente de la Institución Nacional de Derechos Humanos), "en memoria de María Claudia García de Gelman y de todas las personas víctimas del terrorismo de Estado que estuvieron privadas de su libertad en este edificio"; (iii) la publicación en el Diario Oficial, en diarios de amplia circulación nacional y en distintas páginas web oficiales, de la sentencia y del resumen respectivo, y (iv) el pago de las cantidades fijadas por concepto de indemnización -daño material e inmaterial-y por el reintegro de costas y gastos.

5. Las acciones anteriores emprendidas por el Estado uruguayo constituyen una manifestación clara de su compromiso para el cumplimiento de la Sentencia que debe resaltarse. Particularmente, respecto del acto público de reconocimiento de responsabilidad internacional en la que participó la máxima autoridad de dicho país con una amplia difusión por los medios de comunicación y de la colocación de la placa, el Tribunal Interamericano en la presente Resolución de supervisión destacó que "satisface plenamente el objeto y propósito de la reparación dispuesta, en uno de los actos más destacables entre los que han sido realizados por los Estados en cumplimiento de medidas de reparación de esa naturaleza". 7

6. Asimismo, en la propia audiencia privada la Corte IDH tuvo conocimiento de otros actos del Estado uruguayo dirigidos de manera importante al cumplimiento del fallo, fundamentalmente: a) la promulgación de la Ley No 18.831 de 27 de octubre de 2011, denominada "Pretensión Punitiva del Estado: Restablecimiento para los delitos cometidos en aplicación del terrorismo de Estado hasta el $1^{\circ}$ de marzo de $1985^{\prime} ;{ }^{8}$ y b) el Decreto 323/2011 de 30 de junio del mismo año,

\footnotetext{
7 Considerando 8 de la Resolución de supervisión de cumplimiento de Sentencia en el Caso Gelman Vs. Uruguay, a que se refiere el presente voto razonado.

8 Los cuatro artículos de esta Ley No 18.831 (ley interpretativa de la Ley de Caducidad) establecen:

"Artículo $1^{\circ}$.- Se restablece el pleno ejercicio de la pretensión punitiva del Estado para los delitos cometidos en aplicación del terrorismo de Estado hasta el $1^{\circ}$ de marzo de 1985, comprendidos en el artículo $1^{\circ}$ de la Ley No 15.848 de diciembre de 1986.
} 
mediante el cual revoca los actos administrativos y mensajes del Poder Ejecutivo "en aplicación del artículo $3^{\circ}$ de la Ley de Caducidad, que consideran que los hechos denunciados estaban comprendidos en las disposiciones del artículo $1^{\circ} \mathrm{de}$ la referida Ley y en su lugar declárase que dichos hechos no estaban comprendidos en la citada norma legal".

7. Estos actos de los Poderes Legislativo (Ley No 18.831) y Ejecutivo (Decreto 323/2011) fueron valorados de manera positiva por el Tribunal Interamericano, al estar dirigidos al cumplimiento de la Sentencia del Caso Gelman, al estimar que tienen, aparentemente, la finalidad de remover el obstáculo principal que representa la Ley No 15.848 (Ley de Caducidad), ${ }^{9}$ declarada "sin efectos" en la Sentencia de la Corte IDH por su incompatibilidad con las obligaciones establecidas en la Convención Americana y la Convención Interamericana sobre Desaparición Forzada de Personas. Dicha normativa fue declarada incompatible con estos instrumentos internacionales. ${ }^{10}$ La Ley de Caducidad impidió la investigación, el juzgamiento y eventual sanción a los responsables de los hechos en el Caso

Artículo $2^{\circ}$.- No se computará plazo alguno, procesal, de prescripción o de caducidad, en el período comprendido entre el 22 de diciembre de 1986 y la vigencia de esta ley, para los delitos a que refiere el artículo $1^{\circ}$ de esta ley.

Artículo $3^{\circ}$.- Declárase que, los delitos a que refieren los artículos anteriores, son crímenes de lesa humanidad de conformidad con los tratados internacionales de los que la República es parte.

Artículo $4^{\circ}$.- Esta ley entrará en vigencia a partir de su promulgación por el Poder Ejecutivo".

9 Los artículos $1^{\text {o } ~ y ~} 3^{\circ}$ de la Ley No 15.848 de 22 de diciembre de 1986 (publicada D.O. 28 dic/986 No 22295): "Funcionarios militares y policiales. Se reconoce que ha caducado el ejercicio de la pretensión punitiva del Estado respecto de los delitos cometidos hasta el $1^{\circ}$ de marzo de 1985", establecen lo siguiente: "Artículo 10.- Reconócese que, como consecuencia de la lógica de los hechos originados por el acuerdo celebrado entre partidos políticos y las Fuerzas Armadas en agosto de 1984 y a efecto de concluir la transición hacia la plena vigencia del orden constitucional, ha caducado el ejercicio de la pretensión punitiva del Estado respecto de los delitos cometidos hasta el $1^{\circ}$ de marzo de 1985 por funcionarios militares y policiales, equiparados y asimilados por móviles políticos o en ocasión del cumplimiento de sus funciones y en ocasión de acciones ordenadas por los mandos que actuaron durante el período de facto".

"Artículo $3^{\circ}$.- A los efectos previstos en los artículos anteriores, el Juez interviniente en las denuncias correspondientes, requerirá al Poder Ejecutivo que informe, dentro del plazo perentorio de treinta días de recibida la comunicación, si el hecho investigado lo considera comprendido o no en el artículo $1^{\circ}$ de la presente ley. Si el Poder Ejecutivo así lo comunicare, el Juez dispondrá la clausura y el archivo de los antecedentes. Si en cambio, no contestare o informa que no se halla comprendido dispondrá continuar la indagatoria. Desde la fecha de promulgación de esta ley hasta que el Juez reciba la comunicación del Poder Ejecutivo quedan suspendidas todas las diligencias presumariales en los procedimientos mencionados en el inciso primero de este artículo".

10 Caso Gelman Vs. Uruguay. Fondo y Reparaciones. Sentencia de 24 de febrero de 2011. Serie C No 221, párrafo 312, Punto Resolutivo 6, en relación con lo establecido en los párrafos 237 a 241 y 246. 
Gelman, así como también los de otros casos de graves violaciones de derechos humanos acontecidos en Uruguay en esa época.

8. Sin embargo, nueve días después de celebrada la audiencia privada de referencia, se produjo un "hecho nuevo" que ha sido motivo de especial atención por la Corte IDH al resolver sobre la supervisión de cumplimiento de sentencia. En efecto, el Tribunal Interamericano tuvo conocimiento del fallo de la Suprema Corte de Justicia de la República Oriental del Uruguay de 22 de febrero de 2013,11 en la que por mayoría de votos declaró parcialmente procedente la excepción de inconstitucionalidad y declaró inaplicables a los excepcionantes los artículos $2^{\circ}$ y $3^{\circ}$ de la Ley No 18.831.

9. Ante este estado de cosas, la Corte IDH en la presente Resolución de supervisión de cumplimiento de sentencia, analizó las implicaciones y consecuencias que dicho fallo nacional tiene en el cumplimiento de la Sentencia del Tribunal Interamericano y concluyó que la resolución de 22 de febrero de 2013 de la Suprema Corte de Justicia del Uruguay afecta el debido cumplimiento de la Sentencia en el Caso Gelman; por lo que el Tribunal Interamericano se pronunció sobre varios aspectos de vital importancia para el futuro del Sistema Interamericano de Derechos Humanos. Estas circunstancias motivan la necesidad de formular el presente voto concurrente razonado; en la inteligencia de que si bien el suscrito no integraba dicho órgano colegiado cuando se dictó la Sentencia de fondo y reparaciones en febrero de 2011, ahora como nuevo miembro del Tribunal Interamericano, al igual que mis pares, me encuentro no sólo facultado, sino obligado de velar por el debido cumplimiento de la misma.

10. De ahí que si bien comparto íntegramente los razonamientos y el sentido de la presente Resolución de supervisión de cumplimiento de sentencia, adoptada por unanimidad de votos, estimo conveniente, dada la importancia de las consideraciones que la contienen, agregar a la Resolución el presente voto concurrente razonado, con la finalidad de profundizar y destacar tres cuestiones cruciales que influyen en el buen entendimiento de la función jurisdiccional de la Corte Interamericana como aplicador e intérprete de la Convención Americana sobre Derechos Humanos. Esto, en la medida en que sus decisiones repercuten en la funcionalidad del Sistema Interamericano, particularmente en el debido cumplimiento y eficacia de sus sentencias. Así, se abordan a continuación tres temas: (i) la incidencia de

11 Sentencia No 20. IUE-2-109971/2011. Ministro Relator: Doctor Jorge O. Chediak González. Disidencia del Ministro Ricardo C. Pérez Manrique. 
la sentencia de la Suprema Corte de Justicia del Uruguay de 22 de febrero de 2013 en el debido e integral cumplimiento de la Sentencia de la Corte IDH en el Caso Gelman (párrs. 11-21); (ii) la eficacia de la sentencia interamericana y la autoridad de la cosa juzgada internacional: su proyección directa hacia las partes (res judicata) e indirecta hacia los Estados Partes de la Convención Americana (res interpretata) (párrs. 22-79), y (iii) la autoridad de la "cosa juzgada internacional" en relación con el "control de convencionalidad” (párrs. 80-100).

\section{Incidencia de la Sentencia de la Suprema Corte de Justicia del URUGUAY DE 22 DE FEBRERO DE 2013 EN EL DEBIDO E INTEGRAL CUmplimiento de la Sentencia de la Corte IDH en el CASo Gelman}

11. La sentencia de la Suprema Corte de Justicia del Uruguay incide de manera directa en el debido e integral cumplimiento de la Sentencia de la Corte IDH en el Caso Gelman Vs. Uruguay, en tanto confronta el derecho de las víctimas a la reparación integral amparadas en una sentencia internacional, que ha producido la autoridad de cosa juzgada.

12. En efecto, al declararse la inaplicabilidad de los artículos $2^{\circ}$ y $3^{\circ}$ de la Ley No 18.831 en un caso similar al Caso Gelman, es decir, que versa sobre desaparición forzada de personas cuyos hechos acontecieron en el mismo período de dictadura militar, trae como consecuencia la prescripción de delitos que expresamente la Corte IDH en la Sentencia declaró como "imprescriptibles", al constituir por su propia naturaleza una violación de normas jus cogens. ${ }^{12}$ Lo anterior es de particular importancia, debido a que actualmente se lleva a cabo (según lo informado por las partes) el procesamiento de varias personas por el "homicidio" de María Claudia García de Gelman, sin que comprenda hasta ahora otras conductas constitutivas de graves violaciones a los derechos humanos, ni se estén investigando los hechos de la desaparición forzada por supresión de identidad, por lo que el criterio interpretativo del Alto Tribunal uruguayo incide potencialmente en la investigación de los hechos en el Caso Gelman, al establecer dicho fallo nacional que la vigencia de la Ley de Caducidad no afectaría los términos de prescripción de los delitos referidos a hechos constitutivos de graves violaciones de derechos humanos. ${ }^{13}$ En la Sentencia de la Corte IDH en el Caso Gelman Vs. Uruguay de 2011 se expresó que "el proceso

\footnotetext{
12 Caso Gelman Vs. Uruguay. Fondo y Reparaciones. Sentencia de 24 de febrero de 2011. Serie C No 221, párrs. 99, 183, 225 y 254.

13 Considerandos 32 y 48 de la Resolución de 20 de marzo de 2013 de supervisión de cumplimiento de Sentencia en el Caso Gelman Vs. Uruguay, a que se refiere el presente voto razonado.
} 
iniciado por Juan Gelman y reabierto en 2008 por gestiones de María Macarena Gelman, lo ha sido bajo la figura de homicidio, excluyendo otros delitos como la tortura, desaparición forzada y sustracción de identidad, con la que se hace posible que la causa sea declarada prescrita, por los tribunales nacionales". ${ }^{14}$ (Cursivas nuestras).

13. Si bien de conformidad con el derecho procesal constitucional uruguayo la sentencia de la Suprema Corte implica la desaplicación de las normas declaradas inconstitucionales para el caso particular-sin afectar la vigencia de la norma y otros casos judiciales-, ${ }^{15}$ en realidad el efecto interpretativo de la norma se expande, al crearse un criterio jurisprudencial del más alto valor en el ámbito nacional (al emitirse por el máximo órgano jurisdiccional nacional) y cuyas consideraciones difieren de las realizadas por la Corte IDH en la Sentencia del Caso Gelman; lo anterior provoca, evidentemente, que en la práctica los jueces nacionales que estén conociendo de violaciones graves de derechos humanos, tengan la falsa disyuntiva de aplicar de manera "directa" la interpretación que se deriva del fallo de la Corte IDH (que es lo que corresponde por la obligación derivada del artículo 68.1 de la Convención Americana) o bien la jurisprudencia de la Suprema Corte de su país.

14. En el Caso Gelman, la Sentencia de la Corte IDH calificó jurídicamente los hechos como "desaparición forzada de personas" que constituye una de las más claras y graves violaciones a los derechos humanos (con mayor razón cuando se realiza a través de un patrón sistemático por estructuras del Estado, calificado como "terrorismo de Estado"); ${ }^{16}$ y en el Resolutivo 11 de la propia Sentencia refiere a que el Estado debe "garantizar" que la Ley de Caducidad no vuelva a representar un "obstáculo" para la investigación, identificación y, si procede, sanción de los responsables. De ahí que derivado de este nuevo criterio interpretativo de la Suprema Corte de Justicia -que de seguirse por los jueces inaplicarían los artículos $2^{\circ}$ y $3^{\circ}$ de la Ley No 18.831 - existe en la práctica una real y potencial afectación a la obligación de investigar los hechos del presente caso y determinar las correspondientes responsabilidades, así como de la obligación del Estado de garantizar que la Ley de Caducidad (Ley No 15.848), al carecer de efectos jurídicos, no vuelva a representar un obstáculo para esos efectos.

14 Caso Gelman Vs. Uruguay. Fondo y Reparaciones. Sentencia de 24 de febrero de 2011. Serie C No 221, párr. 235.

15 El artículo 259 de la Constitución de la República Oriental del Uruguay establece: "El fallo de la Suprema Corte de Justicia se referirá exclusivamente al caso concreto y sólo tendrá efecto en los procedimientos en que se haya pronunciado".

16 Cfr. Caso Gelman Vs. Uruguay. Fondo y Reparaciones. Sentencia de 24 de febrero de 2011. Serie C No 221, párr. 99. 
15. Así, a nuestro entender, es clara la incidencia que el fallo de la Suprema Corte de Justicia del Uruguay tiene en el debido y efectivo cumplimiento de la Sentencia del Caso Gelman, toda vez que permite que la desaparición forzada, tortura o sustracción de identidad y otros hechos, como violaciones graves de derechos humanos cometidas en dicho contexto, resulten prescriptibles ${ }^{17} \mathrm{y}$, por consecuencia, representen un obstáculo real y potencial para que en el caso puedan realmente investigarse, identificarse $y$, eventualmente, sancionarse a los responsables por la desaparición forzada de María Claudia García Iruretagoyena de Gelman y María Macarena Gelman García Iruretagoyena, esta última como consecuencia de la sustracción, supresión y sustitución de su identidad de conformidad con lo establecido en la Sentencia. La Corte IDH en la Sentencia señaló: "Es necesario reiterar que este es un caso de graves violaciones de derechos humanos, en particular desapariciones forzadas, por lo que es ésta la tipificación que debe primar en las investigaciones que corresponda abrir o continuar a nivel interno. Como ya se ha establecido, por tratarse de un delito de ejecución permanente, es decir, cuya consumación se prolonga en el tiempo, al entrar en vigor la tipificación del delito de desaparición forzada de personas, la nueva ley resulta aplicable, sin que ello represente su aplicación retroactiva". 18 (Cursivas nuestras).

16. En este sentido, debe destacarse que el precedente interpretativo que permite la prescripción de dichas violaciones graves de derechos humanos, fue establecido por el máximo órgano jurisdiccional del Uruguay, lo que implica que puede ser simplemente reiterado sin más consideración a través del mecanismo de "resolución anticipada" ${ }^{19}$ o por nuevas decisiones similares; ${ }^{20}$ además, al ser

\footnotetext{
17 La sentencia de referencia de la Suprema Corte de Justicia del Uruguay establece (pp. 18 y 19): “A esto corresponde añadir que, para los delitos cometidos durante la dictadura y amparados por la Ley de Caducidad, no se creó ninguna prescripción especial, sino que, simplemente, regían los mismos términos extintivos que para cualquier otro delito, por lo que, en la especie, no sería de aplicación la condena impuesta por la Corte Interamericana de Derechos Humanos en cuanto a la remoción de las leyes de prescripción establecidas especialmente para esos casos, puesto que no se dictaron leyes de tal naturaleza".

18 Caso Gelman Vs. Uruguay. Fondo y Reparaciones. Sentencia de 24 de febrero de 2011. Serie C No 221, párr. 236.

19 El artículo 519 del Código General del Proceso establece:

Resolución anticipada.- En cualquier estado de los procedimientos y con prescindencia de la situación en que se encontrare el trámite respectivo, la Suprema Corte de Justicia podrá resolver la cuestión, acreditado que fuere uno de los siguientes extremos:

$1^{\circ}$ Que el petitorio hubiere sido formulado por alguna de las partes con la notoria finalidad de retardar o dilatar innecesariamente la secuela principal sobre el fondo del asunto;

$2^{\circ}$ Que existiere jurisprudencia en el caso planteado y se declarare por ese órgano judicial que mantendrá su anterior criterio.

$20 \mathrm{Al}$ menos en otros tres casos posteriores se ha seguido el mismo sentido y criterio interpretativo; $c f r$. Considerando 52 y nota 23 de la Resolución de supervisión de cumplimiento de Sentencia en el Caso Gelman
} 
jurisprudencia del máximo órgano judicial del país -si bien no constituye precedente obligatorio-, puede convertirse en la práctica en una guía interpretativa relevante para los jueces inferiores provocando que sigan la interpretación realizada por el máximo Tribunal uruguayo cuando conozcan de violaciones graves de derechos humanos, como lo es, por ejemplo, la desaparición forzada de personas; lo que llevaría a la inaplicación de los artículos $2^{\circ}$ y $3^{\circ}$ de la Ley $N^{o} 18.831$ y, consecuentemente, provocaría la prescripción de los delitos de esa naturaleza, en clara discordancia con lo establecido en la sentencia internacional derivada del Caso Gelman Vs. Uruguay, que dada su firmeza ha adquirido la autoridad de cosa juzgada internacional.

17. Además, en el supuesto en que los jueces que estén conociendo o que conozcan de las causas sobre violaciones graves a derechos humanos apliquen la Sentencia del Caso Gelman -incluyendo, evidentemente, las consideraciones interpretativas que fundamentan la decisión, que es lo que corresponde al tener obligatoriedad y eficacia directa para todas las autoridades del Estado uruguayo en todos los niveles, en términos del artículo 68.1 de la Convención Americana-; y llegaran las causas ante la instancia de la Suprema Corte por medio de las vías impugnativas correspondientes, existe en la actualidad un criterio interpretativo que permitiría que la vigencia de Ley de Caducidad continúe, en la práctica, teniendo efectos, al permitirse la prescripción respecto de los delitos que resultan imprescriptibles en términos de la Sentencia del Tribunal Interamericano; y, consecuentemente, la jurisprudencia nacional constituye al día de hoy un obstáculo real y potencial para la investigación de los hechos, juzgamiento y eventual sanción de los responsables, cuestión que genera una situación jurídica contraria a lo previsto en la Sentencia del Caso Gelman, al establecer que "las autoridades se abstengan de realizar actos que impliquen la obstrucción del proceso investigativo". ${ }^{21}$ Sobre el particular, incluso, el propio Estado "reconoce que el reciente fallo del máximo órgano del Poder Judicial podría generar dificultades a los pronunciamientos judiciales vinculados a las causas por violaciones a los derechos humanos ocurridos en el pasado".22 (Cursivas nuestras).

Vs. Uruguay, a que se refiere el presente voto concurrente razonado.

21 Caso Gelman Vs. Uruguay. Fondo y Reparaciones. Sentencia de 24 de febrero de 2011. Serie C No 221, párr. 254.

22 Informe CDH-12.607/176 suscrito por el Agente de la República Oriental del Uruguay, en relación al escrito presentado por CEJIL relativo a la presentación de la copia de la sentencia de la Suprema Corte de Justicia de la Nación de Uruguay de 22 de febrero de 2013. En el mismo informe, se señala que "El caso planteado ante la Suprema Corte de Justicia y donde recayera la sentencia que se menciona no refiere 
18. Por otra parte, la incidencia del fallo de la Suprema Corte de Justicia uruguaya también se advierte hacia el derecho de las víctimas de otras graves violaciones de derechos humanos similares acontecidas en Uruguay, más allá de las víctimas concretas del Caso Gelman. En efecto, no debe pasar inadvertido que en la Sentencia del Caso Gelman se declaró "sin efectos" la Ley de Caducidad. Lo anterior implica que al carecer de efectos jurídicos esa norma general, consecuentemente, tiene incidencia en otros casos donde sea aplicada o pueda tener efectos. En la Sentencia del Caso Gelman así se consideró, al señalar: "En consecuencia, el Estado debe disponer que ninguna otra norma análoga [a la Ley de Caducidad], como prescripción, irretroactividad de la ley penal, cosa juzgada, ne bis in idem o cualquier excluyente similar de responsabilidad, sea aplicada y que las autoridades se abstengan de realizar actos que impliquen la obstrucción del proceso investigativo". ${ }^{23}$ (Cursivas nuestras).

19. Esta última consideración no sólo involucra a la investigación y eventual sanción de los responsables de las graves violaciones de derechos humanos cometidas a las víctimas del Caso Gelman; en efecto, la Corte IDH estableció en la Sentencia que "el Estado deberá asegurar que aquélla [Ley de Caducidad], no vuelva a representar un obstáculo para la investigación de los hechos materia del presente caso ni para la identificación y, si procede, sanción de los responsables de los mismos y de otras graves violaciones de derechos humanos similares acontecidas en Uruguay". ${ }^{24}$ Esta última parte es clara y se refiere a que no se limita exclusivamente a las víctimas en el caso concreto, sino en general, se entiende referida a cualquier víctima derivada de la aplicación de la Ley de Caducidad al haberse declarado dicha ley "sin efectos", precisamente para que no vuelva a constituir un obstáculo para la investigación, juzgamiento y, en su caso, sanción de los responsables por las violaciones graves a los derechos humanos que, como la desaparición forzada de personas, resulta imprescriptible. Lo anterior se corrobora con los párrafos 231 y 232 de la propia Sentencia:

\footnotetext{
concretamente al caso Gelman sino a otro juicio pero en el cual también se investigan hechos ocurrido en igual periodo dictatorial. Si bien, por lo dicho, en cuanto al alcance al caso particular de la decisión de la SCJ no afectaría la causa Gelman, es dable señalar que existen en este mismo momento otros numerosos casos presentados ante la Suprema Corte de Justicia, los que tratan también de denuncias de hechos ocurridos durante el periodo dictatorial, a la espera de pronunciamiento de la Suprema Corte de Justicia por iguales cuestionamientos en relación a la constitucionalidad de la Ley No 18.831" (Cursivas nuestras).

23 Caso Gelman Vs. Uruguay. Fondo y Reparaciones. Sentencia de 24 de febrero de 2011. Serie C No 221, párr. 254.

24 Caso Gelman Vs. Uruguay. Fondo y Reparaciones. Sentencia de 24 de febrero de 2011. Serie C No 221, párr. 253.
} 
231. La falta de investigación de las graves violaciones de derechos humanos cometidas en este caso, enmarcadas en patrones sistemáticos, revelan un incumplimiento de las obligaciones internacionales del Estado, establecidas por normas inderogables 25 . (Cursivas nuestras).

232. Dada su manifiesta incompatibilidad con la Convención Americana, las disposiciones de la Ley de Caducidad que impiden la investigación y sanción de graves violaciones de derechos humanos carecen de efectos jurídicos $\mathrm{y}$, en consecuencia, no pueden seguir representando un obstáculo para la investigación de los hechos del presente caso y la identificación y el castigo de los responsables, ni pueden tener igual o similar impacto respecto de otros casos de graves violaciones de derechos humanos consagrados en la Convención Americana que puedan haber ocurrido en el Uruguay26. (Cursivas nuestras).

20. Este criterio establecido con precisión y claridad en la Sentencia no es una novedad en la jurisprudencia interamericana. Así, desde el Caso Barrios Altos de 2001, la Corte IDH determinó en el fondo del asunto que en el caso peruano las leyes de amnistía "carec[ían] de efectos jurídicos y no p[odian] seguir representando un obstáculo para la investigación de los hechos [del] caso ni para la identificación y el castigo de los responsables, ni p[odian] tener igual o similar impacto respecto de otros casos de violación de los derechos consagrados en la Convención Americana acontecidos en el Perú" ${ }^{27}$ Los alcances generales de esta declaratoria quedaron claros en la resolución de interpretación del mismo caso en donde el Tribunal Interamericano señaló que "dada la naturaleza de la violación constituida por las leyes de amnistía $N^{o} 26479$ y No 26492, lo resuelto en la sentencia de fondo en el caso Barrios Altos tenía] efectos generales". 28 (Cursivas nuestras).

21. En definitiva, a nuestro entender el fallo de la Suprema Corte de Justicia del Uruguay de 22 de febrero de 2013, si bien parte de la aceptación y obligatoriedad

25 "Cfr. Caso Goiburú y otros Vs. Paraguay, Fondo, Reparaciones y Costas. Sentencia de 22 de septiembre de 2006. Serie C No 153, párrs. 93 y 128; Caso Ibsen Cárdenas e Ibsen Peña Vs. Bolivia. Fondo, Reparaciones y Costas. Sentencia de 1 de septiembre de 2010 Serie C No 217, párrs. 61 y 197, y Caso Gomes Lund y otros (Guerrilha do Araguaia) Vs. Brasil. Sentencia de 24 de noviembre de 2010. Excepciones Preliminares, Fondo, Reparaciones y Costas, párr. 137".

26 "Cfr. Caso Barrios Altos. Fondo, supra nota 288, párr. 44; Caso La Cantuta Vs. Perú. Fondo, Reparaciones y Costas. Sentencia de 29 de noviembre de 2006. Serie C No 162, párr. 175, y Caso Gomes Lund y otros (Guerrilha do Araguaia), supra nota 16, párr. 174".

27 Caso Barrios Altos Vs. Perú. Fondo. Sentencia de 14 de marzo de 2001. Serie C No 75, párr. 44.

28 Caso Barrios Altos Vs. Perú. Interpretación de la Sentencia de Fondo. Sentencia de 3 de septiembre de 2001. Serie C No 83, párr. 18. 
de la Sentencia de la Corte IDH, ${ }^{29}$ por su particular interpretación, consideraciones y efectos que produce, incide de manera directa y potencial en el debido cumplimiento de la Sentencia del Caso Gelman, al constituir una interpretación contraria no sólo a la Sentencia internacional que adquirió la autoridad de cosa juzgada, sino en general al Derecho Internacional y, particularmente, al Derecho Internacional de los Derechos Humanos, lo que podría producir un quebrantamiento al acceso a la justicia de las víctimas de graves violaciones de derechos humanos, y podría representar un instrumento de perpetuación de la impunidad y el olvido de esos hechos al permitir la prescripción de dichos delitos; ${ }^{30}$ siendo que las violaciones graves a los derechos humanos, como lo es la desaparición forzada de personas, constituye "por la naturaleza de los derechos lesionados, una violación de una norma jus cogens, especialmente grave por haber acontecido como parte de una práctica sistemática de 'terrorismo de Estado' a nivel inter-estatal”, ${ }^{31}$ y revelan un incumplimiento de las obligaciones internacionales del Estado establecidas por normas inderogables.

\section{EFICACIA DE LA SENTENCIA INTERAMERICANA Y LA AUTORIDAD DE LA COSA JUZGADA INTERNACIONAL: SU PROYECCIÓN DIRECTA HACIA LAS PARTES (RES JUdiCATA) E INDIRECTA HACIA LOS Estados PaRTeS DE la CONVENCión Americana (res INTERPRETATA) A) Eficacia vinculante de la sentencia internacional}

22. De conformidad con los artículos 67 y 68.1 de la Convención Americana sobre Derechos Humanos, el fallo de la Corte IDH será "definitivo" e "inapelable" y los Estados Partes en la Convención se comprometen a "cumplir la decisión" en todo caso en que sean partes. Estos dispositivos convencionales constituyen

\footnotetext{
29 Expresa la sentencia en uno de sus pasajes: "Por lo que viene de expresarse, no cabe duda que las sentencias emanadas de la Corte Interamericana de Derechos Humanos son actos jurisdiccionales producidos por dicho órgano internacional, cuya jurisdicción y competencia ha sido reconocida expresamente por Uruguay, en el momento del depósito del instrumento de ratificación de la Convención Americana sobre Derechos Humanos. Se deriva de ello que-en observancia de su obligación internacional-nuestro país, como Estado condenado, debe proceder de buena fe a dar cumplimiento a lo dictaminado por dicha Corte". (Sentencia No 20 de la Suprema Corte de Justicia del Uruguay, de 22 de febrero de 2013, página 13, segundo párrafo).

30 Cfr. Considerando 103 de la Resolución de cumplimiento de Sentencia en el Caso Gelman Vs. Uruguay, a que se refiere el presente voto razonado.

31 Caso Gelman Vs. Uruguay. Fondo y Reparaciones. Sentencia de 24 de febrero de 2011. Serie C No 221, párr. 99.
} 
el fundamento principal en el marco del Pacto de San José para otorgar a las sentencias del Tribunal Interamericano su carácter "firme" y "con eficacia vinculante" en sus términos, por lo que no procede ningún medio de impugnación ${ }^{32}$ $y$, en consecuencia, no pueden ser revisadas en el ámbito nacional por ninguna autoridad. ${ }^{33}$

23. La "eficacia vinculante" de las sentencias se corrobora, además, con el artículo 68.2 del propio Pacto de San José, al señalar que la indemnización compensatoria "podrá ejecutarse en el respectivo país por el procedimiento interno vigente para la ejecución de sentencias contra el Estado”. Y también del artículo 65, in fine, de la misma Convención, ${ }^{34}$ que señala la posibilidad de la Corte IDH de someter a la consideración de la Asamblea General de la Organización de Estados Americanos, dentro de su informe anual las recomendaciones pertinentes cuando "un Estado no haya dado cumplimiento a sus fallos". Es decir, en todo caso existe la obligación de los Estados de cumplir con el fallo internacional de manera directa, pronta, íntegra y efectiva, siendo la propia Convención Americana la que establece garantías para lograr su cumplimiento; en primer término, la posibilidad de que la Corte IDH supervise dicho cumplimiento derivada de su facultad jurisdiccional y, eventualmente, prevé la posibilidad del propio Tribunal Interamericano para someter a una instancia política el incumplimiento; 35

\footnotetext{
32 Existe una instancia de interpretación de la sentencia, previsto en el artículo 67 de la Convención Americana sobre Derechos Humanos, que pueden presentar las partes dentro de los noventa días a partir de la fecha de la notificación del fallo. Esta instancia, sin embargo, no constituye propiamente un recurso, ya que sólo tiene como finalidad aclarar el sentido o alcance de la resolución, sin que pueda en modo alguno modificar o cambiar su sustancia. Así lo ha entendido de manera reiterada la Corte IDH. Véase, por ejemplo, la Resolución de 15 de mayo de 2011, Interpretación de la Sentencia de Excepción Preliminar, Fondo, Reparaciones y Costas, Caso Fernández Ortega y Otros Vs. México, párrafo 11: "una solicitud de interpretación de sentencia no debe utilizarse como medio de impugnación de la decisión cuya interpretación se requiere. Dicha solicitud tiene como objeto, exclusivamente, determinar el sentido de un fallo cuando alguna de las partes sostiene que el texto de sus puntos resolutivos o de sus consideraciones carece de claridad o precisión, siempre y cuando esas consideraciones incidan en dicha parte resolutiva. Por lo tanto, no se puede pedir la modificación o anulación de la sentencia respectiva a través de una solicitud de interpretación”.

33 Artículo 31.3 del Reglamento de la Corte Interamericana de Derechos Humanos.

34 En el mismo sentido se prevé esta posibilidad en el artículo 30 del Estatuto de la Corte Interamericana.

35 En el último informe de labores del Presidente de la Corte Interamericana correspondiente al año 2012, página 68, precisamente se hace del conocimiento de la Asamblea General de la OEA que: "La Corte Interamericana con fecha 23 de noviembre de 2012 emitió una resolución en donde estableció la negativa de Venezuela a dar cumplimiento a la sentencia de fecha 5 de agosto de 2008 en el caso Apitz Barbera y otros Vs. Venezuela. De conformidad con el artículo 65 de la Convención Americana, la Corte informa a la Asamblea
} 
sin que ello signifique que la Corte IDH deje de conocer de la supervisión de cumplimiento respectivo, por lo que "podrá seguir requiriendo al Estado que presente información relativa al cumplimiento de la Sentencia respectiva cuando lo considere pertinente". 36

24. Como se enfatiza en la Resolución de supervisión de cumplimiento de Sentencia a que se refiere el presente voto razonado, la obligación de acatar el fallo de la Corte IDH de conformidad con las disposiciones convencionales anteriores, derivan del principio básico sobre la responsabilidad internacional del Estado, respaldada ampliamente por la jurisprudencia internacional, que implica el cumplimiento de buena fe de los instrumentos internacionales (pacta sunt servanda), sin que puedan invocarse razones de orden interno -incluso una norma constitucional o decisión judicial-para dejar de asumir la responsabilidad internacional en términos de los artículos 26 y 27 de la Convención de Viena sobre el Derecho de los Tratados. Desde hace tiempo la Corte IDH así lo ha considerado, al establecer que:

Según el derecho internacional las obligaciones que éste impone deben ser cumplidas de buena fe y no puede invocarse para su incumplimiento el derecho interno. Estas reglas pueden ser consideradas como principios generales del derecho y han sido aplicadas, aun tratándose de disposiciones de carácter constitucional, por la Corte Permanente de Justicia Internacional y la Corte Internacional de Justicia [Caso de las Comunidades Greco-Búlgaras (1930), Serie B, No 17, p. 32; Caso de Nacionales Polacos de Danzig (1931), Series A/B, No 44, p. 24; Caso de las Zonas Libres (1932), Series A/B, No 46, p. 167; Aplicabilidad de la obligación a arbitrar bajo el Convenio de Sede de las Naciones Unidas (Caso de la Misión del PLO) (1988), págs. 12, a 31-2, párr. 47]. Asimismo estas reglas han sido codificadas en los artículos 26 y 27 de la Convención de Viena sobre el Derecho de los Tratados de 1969.37

25. Una vez que la sentencia interamericana es notificada a las partes de conformidad con el artículo 69 del mismo Pacto, produce la "eficacia de la sentencia" y, por consecuencia, nace la obligación internacional del Estado que participó en

General de la OEA que Venezuela no ha dado cumplimiento a la sentencia mencionada, por lo que solicita que inste a dicho Estado a cumplir con la sentencia de la Corte".

36 Supervisión de cumplimiento de sentencia. Caso Apitz Barbera y Otros ("Corte Primera de lo Contencioso Administrativo") Vs. Venezuela. Resolución de 23 de noviembre de 2012, Considerando 48.

37 Opinión Consultiva OC-14/94 de 9 de diciembre de 1994. Responsabilidad internacional por expedición y aplicación de leyes violatorias de la Convención (arts. 1 y 2 de la Convención Americana sobre Derechos Humanos). Serie A No 14, párr. 35. Asimismo, estas consideraciones han sido reiteradamente señaladas por el Tribunal Interamericano en casos contenciosos. 
el proceso internacional -donde tuvo la oportunidad procesal para su adecuada defensa-, de "cumplir la decisión de la Corte" de manera pronta, íntegra y efectiva, dentro de los plazos señalados en el propio fallo. La obligación internacional de cumplir con "la decisión" comprende al Estado en su conjunto, es decir, a todos los poderes, órganos y autoridades nacionales. 38

\section{B) Autoridad de la cosa juzgada internacional de las sentencias de la Corte Interamericana de Derechos Humanos (formal y material)}

26. La "cosa juzgada" constituye una institución procesal que consiste en "la autoridad y eficacia que adquiere la sentencia judicial cuando no proceden contra ella recursos ni otros medios de impugnación, y cuyos atributos son la coercibilidad, la inmutabilidad y la irrevisibilidad en otro proceso posterior". ${ }^{39}$

27. En el ámbito del derecho internacional público, desde la más temprana jurisprudencia de la Corte Permanente de Justicia Internacional, así como de la Corte Internacional de Justicia, se ha establecido que las decisiones de organismos de carácter jurisdiccional adquieren la fuerza de cosa juzgada y conllevan la obligación de ser cumplidas. ${ }^{40}$ Asimismo, en su momento, se determinó que sería imposible atribuir facultad a una corte nacional de invalidar una decisión de una corte internacional y de negar la existencia de una violación al derecho internacional ya declarada a nivel internacional en un caso concreto. ${ }^{41}$

28. En el ámbito interamericano la sentencia de la Corte IDH produce "autoridad de cosa juzgada internacional". Esto implica que una vez que la sentencia interamericana es notificada a las partes, produce una eficacia vinculante y directa hacia las mismas. En el supuesto de una sentencia estimatoria de condena a un

38 Cfr. Caso Albán Cornejo y otros. Vs. Ecuador. Supervisión de Cumplimiento de Sentencia. Resolución 5 de febrero de 2013, párr. 5; Caso Castillo Petruzzi y otros Vs. Perú. Supervisión de Cumplimiento de Sentencia. Resolución de 17 de noviembre de 1999, Considerando tercero, y Caso Barrios Altos Vs. Perú, Supervisión de Cumplimiento de Sentencia. Resolución de la Corte de 7 de septiembre de 2012, Considerando cuarto.

39 Couture, Eduardo J., voz “cosa juzgada”, en Vocabulario Jurídico, Españoly latín, con traducción de vocablos al francés, italiano, portugués, inglés y alemán, 4ta. ed., corregida, actualizada y ampliada por Ángel Landoni Sosa, Julio César Faira-Editor, Montevideo, 2010, pp. 211 y 212.

40 Cfr. International Court of Justice, Corfu Channel case (preliminary objection), 1948, p. 28; International Court of Justice, Corfu Channel case (compensation), 1949, p. 248, y Nottebohm case (preliminary objection), 1953, p. 123.

41 Cfr. Permanent Court of Justicie, The Factory At Chorzow (Claim for Indemnity) (The Merits), p. 84. 
Estado, todos los poderes, órganos y autoridades del Estado condenado están obligados a cumplir con la sentencia, sin que se requiera algún procedimiento o interpretación interno o nacional para ello.

29. Así, las sentencias de la Corte IDH adquieren la "autoridad de cosa juzgada internacional" debido al carácter "inimpugnable" del fallo que establece el artículo 67 del Pacto de San José; es decir, al no ser sujeta a revisión posible por no preverse ningún medio de impugnación, lo que le da "firmeza" a la sentencia, como acto jurisdiccional que pone fin al proceso internacional -no así al procedimiento, que continúa la supervisión de la sentencia que deriva de la actividad jurisdiccional del Tribunal Interamericano hasta que se cumple de manera íntegra con la misma-.

30. Ahora bien, al producirse la "autoridad de la cosa juzgada internacional" (producto de la firmeza del fallo) deviene la "inmutabilidad" de la sentencia dictada por la Corte IDH, en tanto acto procesal y en cuanto a su contenido o sustancia y sobre todos sus efectos. Así, la cosa juzgada internacional (formal y material) implica que ningún otro tribunal internacional o nacional -incluso la propia Corte IDH- en otro juicio posterior, puede volver a pronunciarse sobre el objeto del proceso. Esta institución descansa en los principios generales del derecho de seguridad jurídica y de paz social, al permitir certeza a las partes $-\mathrm{y}$ a la sociedad en su conjunto-, al evitar que el conflicto se prolongue indefinidamente, elementos contenidos en los artículos 67 y 68 del Pacto de San José para coadyuvar al establecimiento de un orden público interamericano.

\section{C) Eficacia de la sentencia interamericana como "cosa juzgada" (res judicata) con efectos inter partes y como "norma convencional interpretada" (res interpretata) con efectos erga omnes}

31. La sentencia interamericana, en tanto adquiere la autoridad de la cosa juzgada internacional, despliega los contenidos y efectos de la sentencia en dos dimensiones: a) de manera subjetiva y directa hacia las partes en la controversia internacional; y b) de manera objetiva e indirecta hacia todos los Estados Parte en la Convención Americana.

32. En el primer supuesto se produce una eficacia inter partes, que consiste en la obligación del Estado de cumplir con todo lo establecido en la sentencia interamericana de manera pronta, íntegra y efectiva. Existe una vinculación total y absoluta de los contenidos y efectos del fallo, que se deriva como obligación de los artículos 67 y 68.1 de la Convención Americana. 
33. En el segundo se produce una eficacia erga omnes hacia todos los Estados Parte de la Convención, en la medida en que todas las autoridades nacionales quedan vinculadas a la efectividad convencional y, consecuentemente, al criterio interpretativo establecido por la Corte IDH, en tanto estándar mínimo de efectividad de la norma convencional, derivada de la obligación de los Estados de respeto, garantía y adecuación (normativa e interpretativa) que establecen los artículos $1^{\circ}$ y $2^{\circ}$ de la Convención Americana; y de ahí la lógica de que la sentencia sea notificada no sólo "a las partes en el caso" sino también "transmitido a los Estados partes en la Convención” en términos del artículo 69 del Pacto de San José.

\section{C.1) Eficacia subjetiva de la sentencia interamericana como "cosa juzgada internacional": la vinculación directa "inter partes" implica la obligación del Estado de cumplir con la totalidad de la sentencia y no sólo con la parte dispositiva o resolutiva}

34. La eficacia vinculante de la sentencia que establece responsabilidad internacional a un Estado que fue parte material de la controversia, y en la que tuvo la oportuna y adecuada defensa en juicio, no sólo se proyecta hacia la parte "resolutiva" o "dispositiva" del fallo, sino que alcanzan los razonamientos, argumentos y consideraciones que fundamentan y dan sentido a la decisión. Sólo así se podría entender la buena fe del Estado de cumplir con lo que previamente y en uso de su soberanía se comprometió, esto es, a "cumplir la decisión de la Corte en todo caso" en que sea parte (artículo 68.1 de la Convención Americana); toda vez que no puede desvincularse la parte "dispositiva" o "resolutiva" de la "parte considerativa”, al implicar la sentencia un acto jurisdiccional que involucra, en general, "la decisión" como acto jurisdiccional decisorio.

35. La propia Convención Americana establece la obligación para la Corte IDH de "motivar" su fallo (artículo 66), y es ahí donde se encuentran los "fundamentos de la sentencia"; es decir, el "conjunto de motivos, razones o argumentos de hecho y especialmente de derecho en que se apoya una decisión judicial". 42 Constituyen las consideraciones jurídicas, de hecho y de derecho, aplicables al caso para su resolución. De esta manera, en la motivación se encuentra el thema decidendum que se refleja en los dispositivos o resolutivos de la sentencia y, por lo

42 Couture, Eduardo J., voz "fundamentos de la sentencia", en Vocabulario Jurídico. Español y latín, con traducción de vocablos al francés, italiano, portugués, inglés y alemán, 4ta. ed., corregida, actualizada y ampliada por Ángel Landoni Sosa, Julio César Faira-Editor, Montevideo, 2010, p. 364. 
tanto, constituye "la decisión" un acto complejo del acto decisorio del tribunal. Así, las rationes decidendi constituyen un elemento fundamental y necesario que debe considerar el Estado que fue "parte material" para cumplir adecuadamente y de manera íntegra con los resolutivos y dispositivos de la sentencia.

36. Lo anterior, incluso, fue motivo de reflexión por parte del Tribunal Interamericano desde los primeros casos que conoció, entendiendo que el alcance respectivo tiene su fundamento en un principio general del derecho procesal. Así, en la resolución de reparaciones y costas, en el Caso Velásquez Rodríguez Vs. Honduras, se precisó que:

35. Aunque estas obligaciones no quedaron expresamente incorporadas en la parte resolutiva de la sentencia sobre el fondo, es un principio del derecho procesal que los fundamentos de una decisión judicial forman parte de la misma. La Corte declara, en consecuencia, que tales obligaciones a cargo de Honduras subsisten hasta su total cumplimiento. ${ }^{43}$ (Cursivas nuestras).

37. Un ejemplo de lo anterior por parte de una Alta Corte nacional, se advierte con motivo del cumplimiento de la sentencia en el Caso Radilla Pacheco Vs. México. ${ }^{44}$ La Suprema Corte de Justicia de la Nación de México, motu proprio y sin que estuviera conociendo de un proceso judicial nacional, en cumplimiento de la sentencia interamericana, consideró que la misma le obliga en sus términos. En ese sentido, además de aceptar el "control de convencionalidad ex officio en un modelo de control difuso de constitucionalidad", 45 consideró que "las resoluciones pronunciadas por aquella instancia internacional cuya jurisdicción ha sido aceptada por el Estado mexicano, son obligatorias para todos los órganos del mismo en sus respectivas competencias, al haber figurado como Estado parte en un litigio concreto. Por tanto, para el Poder Judicial son vinculantes no solamente los puntos de resolución concretos de la sentencia, sino la totalidad de los criterios contenidos en la sentencia

43 Caso Velásquez Rodríguez Vs. Honduras. Reparaciones y Costas. Sentencia de 21 de julio de 1989. Serie C No 7 , párr. 35.

44 Caso Radilla Pacheco vs. México. Excepciones Preliminares, Fondo, Reparaciones y Costas. Sentencia de 23 de noviembre de 2009. Serie C, No 209.

45 En cumplimiento explícito al párrafo 339 de la Sentencia de la Corte IDH en el Caso Radilla Pacheco vs. México relativo a la obligación de ejercer "control de convencionalidad ex officio". Cfr. Expediente Varios 912/2010, resuelto por el Tribunal Pleno de la Suprema Corte de Justicia de la Nación el 14 de julio de 2011, párrs. 22 a 36. 
mediante la cual se resuelve ese litigio" ${ }^{46}$ Resulta relevante el criterio interpretativo que sobre el particular adoptó la Suprema Corte de Justicia mexicana en la Tesis núm. LXV/2011:47

"Sentencias emitidas por la Corte Interamericana de Derechos Humanos. Son VINCULANTES EN SUS TÉRMINOS CUANDO EL ESTADO MEXICANO FUE PARTE EN EL LITIGIO. El Estado mexicano ha aceptado la jurisdicción de la Corte Interamericana de Derechos Humanos, por ello, cuando ha sido parte en una controversia o litigio ante esa jurisdicción, la sentencia que se dicta en esa sede, junto con todas sus consideraciones, constituye cosa juzgada, correspondiéndole exclusivamente a ese órgano internacional evaluar todas y cada una de las excepciones formuladas por el Estado mexicano, tanto si están relacionadas con la extensión de la competencia de la misma Corte o con las reservas y salvedades formuladas por aquél. Por ello, la Suprema Corte de Justicia de la Nación, aun como tribunal constitucional, no es competente para analizar, revisar, calificar o decidir si una sentencia dictada por la Corte Interamericana de Derechos Humanos es correcta o incorrecta, o si excede en relación con las normas que rigen su materia y proceso. Por tanto, la Suprema Corte no puede hacer ningún pronunciamiento que cuestione la validez de lo resuelto por la Corte Interamericana de Derechos Humanos, ya que para el Estado mexicano dichas sentencias constituyen cosa juzgada. Lo único procedente es acatar y reconocer la totalidad de la sentencia en sus términos. Así, las resoluciones pronunciadas por aquella instancia internacional son obligatorias para todos los órganos del Estado mexicano, al haber figurado como parte en un litigio concreto, siendo vinculantes para el Poder Judicial no sólo los puntos de resolución concretos de la sentencia, sino la totalidad de los criterios contenidos en ella". (Cursivas nuestras).

38. Ahora bien, el alcance de la vinculación de la ratio decidendi adquiere mayor certeza cuando en los propios dispositivos del fallo refieren de manera expresa a la parte considerativa que contiene los fundamentos jurídicos para la "decisión", como suele ser una práctica reiterada por el Tribunal Interamericano y como aconteció en la Sentencia del Caso Gelman. En efecto, para los efectos que particularmente interesan, resulta relevante lo previsto en el Resolutivo 11:48

\footnotetext{
46 Expediente Varios 912/2010, resuelto por el Tribunal Pleno de la Suprema Corte de Justicia de la Nación el 14 de julio de 2011, párr. 19.

47 Tesis del Tribunal Pleno de la Suprema Corte de Justicia de la Nación, aprobada el 28 de noviembre de 2011 y publicada en el Semanario Judicial de la Federación y su Gaceta, Décima Época, Libro III, diciembre de 2011, tomo 1, p. 556.

48 Caso Gelman Vs. Uruguay. Fondo y Reparaciones. Sentencia de 24 de febrero de 2011. Serie C No 221.
} 
"11. El Estado debe garantizar que la Ley de Caducidad de la Pretensión Punitiva del Estado, al carecer de efectos por su incompatibilidad con la Convención Americana y la Convención Interamericana sobre Desaparición Forzada de Personas, en cuanto puede impedir u obstaculizar la investigación y eventual sanción de los responsables de graves violaciones de derechos humanos, no vuelva a representar un obstáculo para la investigación de los hechos materia del presente caso y para la identificación y, si procede, sanción de los responsables de los mismos, de conformidad con los párrafos 253 y 254 de la Sentencia". (Cursivas nuestras)

39. El "Resolutivo 11" hace referencia precisa a una parte medular de la motivación realizada en el epígrafe "Reparaciones" identificado en los párrafos $253^{49}$ y $254^{50}$ de la Sentencia; lo cual no implica que sólo a dichas consideraciones argumentativas se deba atender para una comprensión adecuada de los fundamentos jurídicos sobre la cuestión decidida, sino en general a las rationes decidendi sobre el thema decidendum que se contienen a lo largo del acto decisorio; es decir, se extienden al conjunto de razonamientos contenidos en la totalidad del fallo que sirvieron al Tribunal Interamericano para decidir sobre la cuestión planteada y debatida en el proceso internacional.

40. De ahí que la motivación que contiene el conjunto de razones y fundamentos de hecho y de derecho plasmadas en la sentencia interamericana, generan la certeza específica para cumplir con lo dispuesto por el Tribunal Interamericano en la Sentencia y, consecuentemente, para cumplir con la Convención Americana en términos del artículo 68.1.

41. En el caso particular, esta certeza sobre lo previsto en el "Resolutivo 11" de la Sentencia, refiere a las consideraciones expuestas a lo largo de la Sentencia y que implican la obligación del Estado de "garantizar" que la Ley de Caducidad no vuelva a representar un obstáculo para la investigación de los hechos, identificación y, si procede, sanción de los responsables de las víctimas del Caso Gelman

\footnotetext{
49 "Para ello, dado que la Ley de Caducidad carece de efectos por su incompatibilidad con la Convención Americana y la Convención Interamericana sobre Desaparición Forzada de Personas, en cuanto puede impedir la investigación y eventual sanción de los responsables de graves violaciones de derechos humanos, el Estado deberá asegurar que aquélla no vuelva a representar un obstáculo para la investigación de los hechos materia del presente caso ni para la identificación y, si procede, sanción de los responsables de los mismos y de otras graves violaciones de derechos humanos similares acontecidas en Uruguay". Caso Gelman Vs. Uruguay. Fondo y Reparaciones. Sentencia de 24 de febrero de 2011. Serie C No 221, párr. 253.

50 "En consecuencia, el Estado debe disponer que ninguna otra norma análoga, como prescripción, irretroactividad de la ley penal, cosa juzgada, ne bis in idem o cualquier excluyente similar de responsabilidad, sea aplicada y que las autoridades se abstengan de realizar actos que impliquen la obstrucción del proceso investigativo". Caso Gelman Vs. Uruguay. Fondo y Reparaciones. Sentencia de 24 de febrero de 2011. Serie C No 221, párr. 254.
} 
$y$ de otros casos de violaciones graves de derechos humanos acontecidos en Uruguay en el período de la dictadura militar, al carecer de efectos jurídicos dicha norma general por contravenir el Pacto de San José y la Convención Interamericana sobre Desaparición Forzada de Personas, resultando imprescriptibles dichas conductas por estar amparadas en normas de jus cogens y por tratarse la desaparición forzada de personas de un delito continuado o permanente; 51 cuestiones abordadas en otras partes del fallo y específicamente en el acápite "VI.3. Derechos a las garantías judiciales y protección judicial en relación con la obligación de respetar los derechos, el deber de adoptar disposiciones en derecho interno y las obligaciones sobre investigación derivadas de la convención interamericana sobre desaparición forzada de personas", comprendidas en los Considerandos 139 a 246 de la Sentencia. Además de lo previsto en el acápite VII. Reparaciones, especialmente los Considerandos 253 y 254 (a que expresamente se refiere el Resolutivo 11 de la Senencia).

42. Es por ello que en la presente Resolución de supervisión de cumplimiento de la Sentencia, la Corte IDH estimó que "la decisión" que emitió - dictada en un caso contencioso concreto, respecto de un Estado Parte en la Convención y que reconoció expresamente su jurisdicción-, 52 no se limita en su efecto vinculante a la parte resolutiva o dispositiva del fallo "sino que incluye todos los fundamentos, motivaciones, alcances y efectos" del mismo; ${ }^{53}$ es decir, la sentencia es vinculante para el Estado concernido en su integridad, incluyendo su ratio decidendi, toda vez que "la obligación de los Estados Parte de dar pronto cumplimiento a las decisiones de la Corte es parte intrínseca de la obligación de cumplir de buena fe con la Convención Americana y vincula a todos los poderes y órganos estatales". ${ }^{54}$

\footnotetext{
51 El Considerando 221 de la Sentencia expresamente señala: "La falta de investigación de las graves violaciones de derechos humanos cometidas en este caso, enmarcadas en patrones sistemáticos, revelan un incumplimiento de las obligaciones internacionales del Estado, establecidas por normas inderogables". Caso Gelman Vs. Uruguay. Fondo y Reparaciones. Sentencia de 24 de febrero de 2011. Serie C No 221, párr. 221.

52 La República Oriental del Uruguay es Estado Parte de la Convención desde el 19 de abril de 1985 y reconoció la competencia contenciosa de la Corte IDH en esa misma fecha. Asimismo, también es parte en la Convención Interamericana para Prevenir y Sancionar la Tortura desde el 10 de noviembre de 1992; en la Convención Interamericana sobre Desaparición Forzada de Personas desde el 2 de abril de 1996; y en la Convención Interamericana para Prevenir, Sancionar y Erradicar la Violencia contra la Mujer desde el 2 de abril de 1996. Tratados sobre los cuales se pronunció y tiene competencia la Corte IDH en términos del artículo 62.3 de la Convención Americana.

53 Considerando 102 de la Resolución de supervisión de cumplimiento de la Sentencia en el Caso Gelman $V$ s. Uruguay, a que se refiere el presente voto razonado.

54 Considerando 62, in fine, de la Resolución de supervisión de cumplimiento de la Sentencia en el Caso Gelman Vs. Uruguay, a que se refiere el presente voto razonado.
} 


\section{C.2) Eficacia objetiva de la sentencia interamericana como "norma convencional interpretada": la vinculación indirecta "erga omnes" hacia todos los Estados Parte de la Convención Americana implica aplicar el estándar interpretativo minimo de efectividad de la norma convencional}

43. La proyección de la eficacia interpretativa de la sentencia hacia todos los Estados Parte que han suscrito y ratificado o se han adherido a la Convención Americana sobre Derechos Humanos, y particularmente en aquellos que han aceptado la competencia contenciosa de la Corte IDH, consiste en la obligación por todas las autoridades nacionales de aplicar no sólo la norma convencional sino la "norma convencional interpretada" (res interpretata); 55 es decir, el criterio interpretativo que como estándar mínimo aplicó el Tribunal Interamericano al Pacto de San José y, en general al corpus juris interamericano, materia de su competencia, para resolver la controversia. Y así asegurar la efectividad (míni$\mathrm{ma}$ ) de la norma convencional. Lo anterior, al constituir precisamente el objeto del mandato y competencia del Tribunal Interamericano "la interpretación y aplicación de la Convención Americana", 56 y "de otros tratados que le otorguen competencia". 57

44. La eficacia interpretativa de la norma convencional debe entenderse como la posibilidad de lograr una efectividad regional estándar mínima de la Convención Americana para ser aplicable por todas las autoridades en el ámbito nacional. Lo anterior se deriva de los artículos $1.1^{58}$ y $2^{59}$ del propio Pacto de San José, en

55 Considerandos 67, 69 y 72 de la Resolución de supervisión de cumplimiento de la Sentencia en el Caso Gelman Vs. Uruguay, a que se refiere el presente voto razonado.

56 Artículos 62.1 y 3 de la Convención Americana y $1^{\circ}$ del Estatuto de la Corte Interamericana. aprobado por la Asamblea General de la OEA en La Paz, Bolivia, en octubre de 1979.

57 Cfr. Caso Ibsen Cárdenas e Ibsen Peña vs. Bolivia, Fondo, Reparaciones y Costas. Sentencia de $1^{\circ}$ de septiembre de 2010. Serie C No 217, párr. 199.

58 "Art. 1. Obligación de Respetar los Derechos. Los Estados Partes en esta Convención se comprometen a respetar los derechos y libertades reconocidos en ella y a garantizar su libre y pleno ejercicio a toda persona que esté sujeta a su jurisdicción, sin discriminación alguna o motivos de raza, color, sexo, idioma, religión, opiniones políticas o de cualquier otra índole, origen nacional o social, posición económica, nacimiento o cualquier otra condición social".

59 "Art. 2. Deber de Adoptar Disposiciones de Derecho Interno. Si el ejercicio de los derechos y libertades mencionados en el artículo 1 no estuviere ya garantizado por disposiciones legislativas o de otro carácter, los Estados Partes se comprometen a adoptar, con arreglo a sus procedimientos constitucionales y a las disposiciones de esta Convención, las medidas legislativas o de otro carácter que fueren necesarias para hacer efectivos tales derechos y libertades". 
virtud de que existe la obligación de los Estados Parte de "respetar" y "garantizar" los derechos y libertades, así como la obligación de "adecuación" -normativa e interpretativa- para lograr la efectividad de los derechos y libertades cuando no estén garantizados. Esta última obligación de los Estados Parte es de singular importancia en el Sistema Interamericano de Derechos Humanos y constituye uno de los aspectos fundamentales que lo distingue del Sistema Europeo. ${ }^{60}$

45. En efecto, el artículo $2^{\circ}$ de la Convención Americana, que se inspira en el artículo 2.2 del Pacto Internacional de Derechos Civiles y Políticos de Naciones Unidas de 1966, ${ }^{61}$ y también recoge el artículo $2^{\circ}$ del Protocolo adicional en materia de Derechos Económicos, Sociales y Culturales de 1988, ${ }^{62}$ ha sido considerado por la Corte IDH no como una obligación implícita de las de "respeto" y "garantía" previstas en el artículo $1^{\circ}$ de la propia Convención, sino una obligación especifica que complementa aquéllas. Desde la Opinión Consultiva 7/86, el Tribunal Interamericano consideró que la obligación derivada del artículo $2^{\circ}$ del Pacto de San José, constituye una "obligación adicional, que se suma a la impuesta por el artículo 1 de la Convención dirigida a hacer más determinante y cierto el respeto de los derechos y libertades que la Convención reconoce. Por eso es que la obligación que resulta del artículo 2, complementa, pero de ninguna manera sustituye o suple, a la obligación general y no condicionada que resulta del artículo 1". ${ }^{63}$

60 La Convención Europea para la Protección de los Derechos Humanos y de las Libertades Fundamentales, adoptada el 4 de noviembre de 1950 por el Consejo de Europa y en vigor desde 1953, no contiene una norma explícita de esta naturaleza.

61 Asamblea General de la ONU, resolución 2200 A (XXI), de 16 de diciembre de 1966, vigente a partir del 23 de marzo de 1976: "Art. 2. Cada Estado Parte se compromete a adoptar, con arreglo a sus procedimientos constitucionales y a las disposiciones del presente Pacto, las medidas oportunas para dictar las disposiciones legislativas o de otro carácter que fueren necesarias para hacer efectivos los derechos reconocidos en el presente Pacto y que no estuviesen ya garantizados por disposiciones legislativas o de otro carácter".

62 Suscrito en San Salvador, El Salvador, el 17 de noviembre de 1988: "Art. 2. Obligaciones de Adoptar Disposiciones de Derecho Interno. Si el ejercicio de los derechos establecidos en el presente Protocolo no estuviera ya garantizado por disposiciones legislativas o de otro carácter, los Estados partes se comprometen a adoptar, con arreglo a sus procedimientos constitucionales y a las disposiciones de este Protocolo las medidas legislativas de otro carácter que fueren necesarias para hacer efectivos tales derechos".

63 Asimismo, se precisa por la Corte IDH que "se propuso la inclusión del actual artículo 2 en el Proyecto de Convención, en las observaciones del Gobierno de Chile al Proyecto de la Convención Interamericana sobre Derechos Humanos: 'La argumentación de que la inclusión de esta cláusula en la Convención Interamericana podría justificar la alegación de un Estado en el sentido de no estar obligado a respetar uno o más derechos no contemplados en su legislación interna, no se sostiene dentro de los términos del proyecto; y menos aún 
46. El carácter evolutivo de la jurisprudencia interamericana ha permitido interpretar el contenido obligacional derivado del artículo $2^{\circ}$ de la Convención Americana de "adoptar disposiciones de derecho interno" sean "medidas legislativas o de otro carácter que fueren necesarias para hacer efectivos" los derechos y libertades. Esto ha motivado una jurisprudencia interamericana amplia sobre diversas temáticas; ${ }^{64}$ por ejemplo, pueblos indígenas o tribales, ${ }^{65}$ libertad de expresión y acceso a la información, ${ }^{66}$ derecho del inculpado a recurrir el fallo ante juez o tribunal superior en materia penal, ${ }^{67}$ pena de muerte, ${ }^{68}$ fuero

si su alcance queda expresamente establecido durante la Conferencia' (Actas y Documentos, supra 4, p. 38)". Exigibilidad del Derecho de Rectificación o Respuesta (arts. 14.1, 1.1 y 2 Convención Americana sobre Derechos Humanos). Opinión Consultiva OC-7/86 de 29 de agosto de 1986. Serie A No 7.

64 Cfr. Ferrer Mac-Gregor, Eduardo y Pelayo Möller, Carlos María, "El deber de adoptar disposiciones de derecho interno. Análisis del artículo $2^{\circ}$ de la Convención Americana sobre Derechos Humanos y su impacto en el orden jurídico nacional", en Von Bogdandy, Armin, Ugartemendia, Juan Ignacio, Saiz Arnaiz, Alejandro, y Morales-Antoniazzi, Mariela (coords.), La tutela jurisdiccional de los derechos. Del constitucionalismo histórico al constitucionalismo de la integración, Instituto Vasco de Administración Pública, Oñati, 2012, pp. 299-348.

65 Caso de la Comunidad Mayagna (Sumo) Awas Tingni vs. Nicaragua. Fondo, Reparaciones y Costas. Sentencia de 31 de agosto de 2001. Serie C, No 79; Caso de la Comunidad Mayagna (Sumo) Awas Tingni vs. Nicaragua. Fondo, Reparaciones y Costas. Sentencia de 31 de agosto de 2001. Serie C, No 79; Caso Comunidad Indígena Yakye Axa vs. Paraguay. Fondo Reparaciones y Costas. Sentencia 17 de junio de 2005; Caso Yatama vs. Nicaragua. Excepciones Preliminares, Fondo, Reparaciones y Costas. Sentencia de 23 de junio de 2005. Serie C, No 127; Caso Comunidad Indígena Sawhoyamaxa vs. Paraguay. Fondo, Reparaciones y Costas. Sentencia de 29 de marzo de 2006; Caso del Pueblo Saramaka. vs. Surinam. Excepciones Preliminares, Fondo, Reparaciones y Costas. Sentencia de 28 de noviembre de 2007; Caso Comunidad Indígena Xákmok Kásek. vs. Paraguay. Fondo, Reparaciones y Costas. Sentencia de 24 de agosto de 2010 Serie C, No 214; Caso Pueblo Indigena Kichwa de Sarayaku Vs. Ecuador. Fondo y Reparaciones. Sentencia de 27 de junio de 2012. Serie C No 245.

66 Cfr. Caso "La Última Tentación de Cristo"(Olmedo Bustos y otros) vs. Chile. Fondo, Reparaciones y Costas. Sentencia de 5 de febrero de 2001 Serie C, No 73; Caso Palamara Iribarne vs. Chile. Fondo, Reparaciones y Costas. Sentencia de 22 de noviembre de 2005. Serie C, No 135; Caso Kimel vs. Argentina. Fondo, Reparaciones y Costas. Sentencia de 2 de mayo de 2008 Serie C No 177; Caso Usón Ramirez vs. Venezuela. Excepción Preliminar, Fondo, Reparaciones y Costas. Sentencia de 20 de noviembre de 2009. Serie C, No 207.

67 Cfr. Caso Barreto Leiva vs. Venezuela. Fondo, Reparaciones y Costas. Sentencia de 17 de noviembre de 2009. Serie C, No 206; Caso Herrera Ulloa vs. Costa Rica. Excepciones Preliminares, Fondo, Reparaciones y Costas. Sentencia de 2 de julio de 2004. Serie C, No 107; Caso Barreto Leiva vs. Venezuela. Fondo, Reparaciones y Costas. Sentencia de 17 de noviembre de 2009. Serie C, No 206.

68 Cfr. Caso Hilaire, Constantine y Benjamin y otros vs. Trinidad y Tobago. Fondo, Reparaciones y Costas. Sentencia de 21 de junio de 2002. Serie C, No 94; Caso Fermín Ramírez vs. Guatemala. Fondo, Reparaciones y Costas. Sentencia de 20 de junio de 2005. Serie C, No 126; Caso Raxcacó Reyes vs. Guatemala. Fondo, Reparaciones y Costas. Sentencia de 15 de septiembre de 2005. Serie C, No 133; Caso Boyce y otros vs. Barbados. Excepción Preliminar, Fondo, Reparaciones y Costas. Sentencia de 20 de noviembre de 2007. Serie 
militar, ${ }^{69}$ derecho laboral, ${ }^{70}$ estabilidad e inamovilidad de jueces, ${ }^{71}$ y sobre leyes de amnistía. ${ }^{72}$ En esta última línea jurisprudencial sobre la incompatibilidad de las leyes de amnistías, como sucedió en la Sentencia del Caso Gelman, ${ }^{73}$ expresamente se concluye en el Resolutivo 6 que "El Estado ha incumplido la obligación de adecuar su derecho interno a la Convención Americana" y específicamente dentro de la motivación, se expresa: ${ }^{74}$

C, No 169; Caso Dacosta Cadogan vs. Barbados. Excepciones Preliminares, Fondo, Reparaciones y Costas. Sentencia de 24 de septiembre de 2009. Serie C, No 204.

69 Cfr. Caso Loayza Tamayo vs. Perú. Fondo. Sentencia de 17 de septiembre de 1997. Serie C, No 33; Caso Castillo Petruzzi y otros vs. Perú. Fondo, Reparaciones y Costas. Sentencia de 30 de mayo de 1999. Serie C, No 52; Caso Las Palmeras vs. Colombia. Fondo. Sentencia de 6 de diciembre de 2001. Serie C, No 90; Caso Radilla Pacheco vs. México. Excepciones Preliminares, Fondo, Reparaciones y Costas. Sentencia de 23 de noviembre de 2009. Serie C, № 209; Caso Fernández Ortega y Otros vs. México. Excepción Preliminar, Fondo, Reparaciones y Costas. Sentencia de 30 de agosto de 2010. Serie C, No 215; Caso Rosendo Cantú y Otra vs. México. Excepción Preliminar, Fondo, Reparaciones y Costas. Sentencia de 31 de agosto de 2010. Serie C, No 216; Caso Cabrera García y Montiel Flores vs. México. Excepciones Preliminares, Fondo, Reparaciones y Costas. Sentencia de 26 de noviembre de 2010, Serie C, No 220.

70 Cfr. Caso Baena Ricardo y otros vs. Panamá. Fondo, Reparaciones y Costas. Sentencia de 2 de febrero de 2001. Serie C, No 72; Caso Cinco Pensionistas vs. Perú. Fondo, Reparaciones y Costas. Sentencia de 28 de febrero de 2003. Serie C, No 98, párrs. 167 y 168; Caso Trabajadores Cesados del Congreso (Aguado Alfaro y otros) vs. Perú. Excepciones Preliminares, Fondo, Reparaciones y Costas. Sentencia de 24 de noviembre de 2006. Serie C, No 158.

71 Cfr. Caso Apitz Barbera y otros ("Corte Primera de lo Contencioso Administrativo") vs. Venezuela. Excepción Preliminar, Fondo, Reparaciones y Costas. Sentencia de 5 de agosto de 2008. Serie C, No 182; Caso Reverón Trujillo vs. Venezuela. Excepción Preliminar, Fondo, Reparaciones y Costas. Sentencia de 30 de junio de 2009. Serie C, No 197; Caso Chocrón Chocrón vs. Venezuela. Excepción Preliminar, Fondo, Reparaciones y Costas. Sentencia de 1 de julio de 2011. Serie C, No 227.

72 Cfr. Caso Barrios Altos vs. Perú. Fondo. Sentencia de 14 de marzo de 2001. Serie C, No 75; Caso Almonacid Arellano y otros vs. Chile. Excepciones Preliminares, Fondo, Reparaciones y Costas. Sentencia de 26 de septiembre de 2006. Serie C, No 154; Caso La Cantuta vs. Perú. Fondo, Reparaciones y Costas. Sentencia de 29 de noviembre de 2006. Serie C, No 162; Caso Gomes Lund y otros (Guerrilha do Araguaia) vs. Brasil. Excepciones Preliminares, Fondo, Reparaciones y Costas. Sentencia de 24 de noviembre de 2010, Serie C, No 219; Caso Gelman Vs. Uruguay. Fondo y Reparaciones. Sentencia de 24 de febrero de 2011 Serie C, No 221; Caso Masacres de El Mozote y lugares aledaños Vs. El Salvador. Fondo, Reparaciones y Costas. Sentencia de 25 de octubre de 2012 Serie C, No 252.

73 La Corte IDH expresamente considera a la Ley de Caducidad como una ley de amnistía. El párr. 240 de la Sentencia señala: "Adicionalmente, al aplicar la Ley de Caducidad (que por sus efectos constituye una ley de amnistía) impidiendo la investigación de los hechos y la identificación, juzgamiento y eventual sanción de los posibles responsables de violaciones continuadas y permanentes como las desapariciones forzadas, se incumple la obligación de adecuar el derecho interno del Estado, consagrada en el artículo 2 de la Convención Americana". Caso Gelman Vs. Uruguay. Fondo y Reparaciones. Sentencia de 24 de febrero de 2011 Serie C, No 221, párr. 240.

74 Caso Gelman Vs. Uruguay. Fondo y Reparaciones. Sentencia de 24 de febrero de 2011 Serie C, No 221, párr. 243. 
"En particular, debido a la interpretación y a la aplicación que se ha dado a la Ley de Caducidad, la cual carece de efectos jurídicos respecto de graves violaciones de derechos humanos en los términos antes indicados (supra párr. 232), ha incumplido su obligación de adecuar su derecho interno a la Convención, contenida en el artículo 2 de la misma, en relación con los artículos 8.1, 25 y 1.1 del mismo tratado y los artículos I.b, III, IV y V de la Convención Interamericana sobre Desaparición Forzada de Personas". (Cursivas nuestras).

47. Así, la expresión "o de otro carácter" contenida la obligación convencional del artículo $2^{\circ}$, implica cualquier medida en la que se incluyen, evidentemente, las "interpretaciones" que las autoridades y especialmente los jueces realizan al Pacto de San José para "hacer efectivos" los derechos y libertades del Pacto, que están obligados a respetar y garantizar en términos del artículo 1.1 de la Convención. En el Caso La Cantuta Vs. Perú se estableció:

"Ciertamente el artículo 2 de la Convención no define cuáles son las medidas pertinentes para la adecuación del derecho interno a la misma, obviamente por depender ello del carácter de la norma que la requiera y las circunstancias de la situación concreta. Por ello, la Corte ha interpretado que tal adecuación implica la adopción de medidas en dos vertientes, a saber: i) la supresión de las normas y prácticas de cualquier naturaleza que entrañen violación a las garantías previstas en la Convención o que desconozcan los derechos allí reconocidos u obstaculicen su ejercicio, y ii) la expedición de normas y el desarrollo de prácticas conducentes a la efectiva observancia de dichas garantias. El Tribunal ha entendido que la obligación de la primera vertiente se incumple mientras la norma o práctica violatoria de la Convención se mantenga en el ordenamiento jurídico y, por ende, se satisface con la modificación, la derogación, o de algún modo anulación, o la reforma de las normas o prácticas que tengan esos alcances, según corresponda". ${ }^{75}$ (Cursivas nuestras).

48. Lo anterior es relevante para advertir que si una interpretación constitucional o legal en el ámbito interno no se ajusta al estándar interpretativo establecido por la Corte IDH para otorgar un mínimo de efectividad a la Convención Americana, existe un incumplimiento de la obligación de "adecuación" previsto en el artículo $2^{\circ}$ del Pacto de San José, es decir, al existir una inadecuada actuación interna con la Convención; en cuanto limita la efectividad de la norma convencional al realizar una interpretación de menores alcances a la realizada por el Tribunal Interamericano, lo cual, además, prohíbe su artículo 29, al permitir que

75 Caso La Cantuta Vs. Perú. Fondo, Reparaciones y Costas. Sentencia de 29 de noviembre de 2006. Serie C, No 162, párr. 172. 
una práctica nacional limite los alcances de la norma convencional en perjuicio de la efectividad de un derecho o libertad. Como lo ha expresado la Corte IDH "la existencia de una norma no garantiza por sí misma que su aplicación sea adecuada. Es necesario que la aplicación de las normas o su interpretación, en tanto prácticas jurisdiccionales y manifestación del orden público estatal, se encuentren ajustadas al mismo fin que persigue el artículo 2 de la Convención". ${ }^{76}$

49. La Corte IDH ha señalado que el deber general del Estado, establecido en el artículo $2^{\circ}$ de la Convención, incluye la adopción de medidas para suprimir las normas y prácticas de cualquier naturaleza que impliquen una violación a los derechos previstas en dicho instrumento internacional, así como la expedición de normas y el desarrollo de prácticas conducentes a la observancia efectiva de los mismos. 77 Aquí la observancia de la "efectividad" cobra relevancia en términos del principio del effet utile "lo que significa que el Estado debe adoptar todas las medidas necesarias para que lo establecido en la Convención sea realmente cumplido"; 78 por lo que la Corte IDH ha considerado necesario reafirmar que dicha obligación, por su propia naturaleza, constituye una obligación de resultado. ${ }^{79}$

50. En este sentido "la obligación estatal de adecuar la legislación interna a las disposiciones convencionales no se limita al texto constitucional o legislativo, sino que deberá irradiar a todas las disposiciones jurídicas de carácter reglamentario y traducirse en la efectiva aplicación práctica de los estándares de protección de los derechos humanos" ${ }^{80}$ Así, la observancia a lo dispuesto en el artículo $2^{\circ}$ del Pacto de San José trasciende el ámbito meramente legislativo, pudiendo y debiendo las autoridades administrativas y especialmente los jueces nacionales en todos los ni-

\footnotetext{
76 Cfr. Caso Radilla Pacheco Vs. México. Excepciones Preliminares, Fondo, Reparaciones y Costas. Sentencia de 23 de noviembre de 2009. Serie C No 209, párr. 338. En el mismo sentido, véanse Caso Castillo Petruzzi y otros Vs. Perú. Fondo, Reparaciones y Costas. Sentencia de 30 de mayo de 1999. Serie C, No 52, párr. 207; Caso Ximenes Lopes Vs. Brasil. Fondo, Reparaciones y Costas. Sentencia de 4 de julio de 2006. Serie C No 149, párr. 83; y Caso Almonacid Arellano y otros Vs. Chile. Excepciones Preliminares, Fondo, Reparaciones y Costas. Sentencia de 26 de septiembre de 2006. Serie C, No 154, párr. 118.

77 Cfr. Caso Durand y Ugarte Vs. Perú. Fondo. Sentencia de 16 de agosto de 2000. Serie C No 68, párr. 137.

78 Caso Comunidad Indigena Yakye Axa Vs. Paraguay. Fondo Reparaciones y Costas. Sentencia 17 de junio de 2005. Serie C, No 125, párr. 101.

79 Cfr. Caso Caesar Vs. Trinidad y Tobago. Fondo, Reparaciones y Costas. Sentencia 11 de marzo 2005. Serie C No 123, párr. 93.

80 Caso Vélez Loor Vs. Panamá. Excepciones Preliminares, Fondo, Reparaciones y Costas. Sentencia de 23 de noviembre de 2010 Serie C No 218, párr. 286.
} 
veles, realizar interpretaciones que no limiten el estándar interpretativo establecido por la Corte IDH precisamente para lograr la efectividad mínima de la Convención Americana, cuyo compromiso los Estados se comprometieron a aplicar.

51. De ahí que la Corte IDH ha entendido que tiene dentro de sus competencias la posibilidad de supervisar un "adecuado control de convencionalidad" sobre la interpretación que realiza una alta jurisdicción nacional, como lo hizo en la Sentencia del Caso Gelman. En efecto, el Tribunal Interamericano estimó que la Suprema Corte de Justicia del Uruguay en el Caso Nibia Sabalsagaray Curutchet de $2009^{81}$ (criterio reiterado por lo menos en dos casos posteriores), 82 había realizado "un adecuado control de convencionalidad" respecto de la Ley de Caducidad, al establecer, inter alia, que:

"el límite de la decisión de la mayoría reside, esencialmente, en dos cosas: la tutela de los derechos fundamentales (los primeros, entre todos, son el derecho a la vida y a la libertad personal, y no hay voluntad de la mayoría, ni interés general ni bien común o público en aras de los cuales puedan ser sacrificados) y la sujeción de los poderes públicos a la ley" 83 .

\footnotetext{
81 Sentencia No 365 de 19 de octubre de 2009. Caso "Sabalsagaray Curutchet Blanca Stela-Denuncia de Excepción de Inconstitucionalidad".

82 Por medio del mecanismo de "resolución anticipada" el criterio se reiteró en la causa "Organización de los Derechos Humanos" de 29 de octubre de 2010 y en la causa "Fusilados de Soca" de 10 de febrero de 2011. Cfr. Considerando 38 y nota 14 de la Resolución de supervisión de cumplimiento de sentencia en el Caso Gelman Vs. Uruguay, a que se refiere el presente voto concurrente razonado.

83 Caso Gelman Vs. Uruguay. Fondo y Reparaciones. Sentencia de 24 de febrero de 2011 Serie C, No 239. En la nota al pie 298 del propio fallo, se sostiene lo siguiente:

"Suprema Corte de Justicia del Uruguay, Caso de Nibia Sabalsagaray Curutchet, supra nota 163:

[...] la ratificación popular que tuvo lugar en el recurso de referéndum promovido contra la ley en 1989 no proyecta consecuencia relevante alguna con relación al análisis de constitucionalidad que se debe realizar $[\ldots]$

Por otra parte, el ejercicio directo de la soberanía popular por la vía del referéndum derogatorio de las leyes sancionadas por el Poder Legislativo sólo tiene el referido alcance eventualmente abrogatorio, pero el rechazo de la derogación por parte de la ciudadanía no extiende su eficacia al punto de otorgar una cobertura de constitucionalidad a una norma legal viciada 'ab origine' por transgredir normas o principios consagrados o reconocidos por la Carta. Como sostiene Luigi Ferrajoli, las normas constitucionales que establecen los principios y derechos fundamentales garantizan la dimensión material de la 'democracia sustancial', que alude a aquello que no puede ser decidido o que debe ser decidido por la mayoría, vinculando la legislación, bajo pena de invalidez, al respeto de los derechos fundamentales y a los otros principios axiológicos establecidos por ella [...] El mencionado autor califica como una falacia metajurídica la confusión que existe entre el paradigma del Estado de Derecho y el de la democracia política, según la cual una norma es legítima solamente si es querida por la mayoría [...]".
} 
52. En todo caso las autoridades nacionales pueden válidamente ampliar la eficacia de la norma convencional a través de la interpretación más favorable en aplicación del principio pro personae, que además obliga al Estado debido a lo previsto en el artículo 29.b) del Pacto de San José, en la medida en que ninguna disposición de esta Convención puede ser interpretada en el sentido de que "limite el goce y ejercicio de cualquier derecho o libertad que pueda estar reconocido de acuerdo con las leyes de cualquiera de los Estados partes o de acuerdo con otra convención en que sea parte uno de dichos Estados".

53. Lo anterior es de importancia para comprender que la eficacia interpretativa de la norma convencional, al constituir un estándar mínimo regional de aplicabilidad nacional constituye una pauta hermenéutica fundamental e imprescindible de minimos en materia de derechos humanos; de tal manera que pueden las autoridades nacionales (administrativas, legislativas o jurisdiccionales) de cualquier nivel (municipal, regional, estadual, federal o nacional) de los Estados Parte de la Convención, eventualmente apartarse del criterio interpretativo de la Corte IDH cuando se realice de manera razonada y fundada una interpretación que permita lograr un mayor grado de efectividad de la norma convencional a través de una interpretación más favorable de la "jurisprudencia interamericana" sobre el derecho humano en cuestión.

54. La eficacia interpretativa de la jurisprudencia interamericana (res interpretata) deriva directamente de la obligación de los Estados Parte de la Convención del respeto, garantía y adecuación (normativa/interpretativa) a que se refieren los artículos $1^{\circ}$ y $2^{\circ}$ del propio Pacto, teniendo en consideración que conforme a la propia Convención Americana la "Corte [Interamericana] tiene competencia para conocer de cualquier caso relativo a la interpretación y aplicación de las disposiciones de esta Convención que le sea sometido" 84 y "dispondrá que se garantice al lesionado en el goce de su derecho o libertad conculcados" cuando decida que hubo violación de los mismos. ${ }^{85}$ Así, la aplicación nacional del estándar interpretativo interamericano asegura el mínimo de efectividad de la norma convencional.

55. En otras palabras, la eficacia interpretativa de la jurisprudencia interamericana hacia todos los Estados Parte de la Convención Americana deriva de la

\footnotetext{
84 Artículo 62.3 de la Convención Americana sobre Derechos Humanos, lo cual se corrobora con el propio artículo 62.1 y el artículo 33.b) del mismo Pacto de San José; además de los artículos $1^{\circ}$ y 2.1 del Estatuto de la Corte Interamericana de Derechos Humanos, este último instrumento internacional aprobado por la Asamblea General de la OEA.

85 Artículo 63.1 de la Convención Americana sobre Derechos Humanos.
} 
misma eficacia jurídica de este instrumento internacional, al desplegar sus efectos en un Estado por el solo hecho de ser Parte del mismo; ${ }^{86}$ y, consecuentemente, para cumplir con su obligación convencional de respeto, garantía y adecuación (normativa/interpretativa) a que se refieren los artículos $1^{\circ}$ y $2^{\circ}$ se requiere una efectividad mínima de la propia Convención Americana, que sólo podría lograrse con la adecuación interpretativa mínima que las autoridades nacionales realicen de la norma convencional a la luz de la jurisprudencia interamericana. Lo anterior, debido a que es el propio Pacto de San José el que establece como único órgano competente de naturaleza "jurisdiccional" para conocer de los asuntos relacionados con el cumplimiento de los compromisos contraídos por los Estados Parte de la Convención Americana, con competencia para "interpretar" y "aplicar" la Convención, ${ }^{87}$ y en caso de existir una violación garantice al lesionado en el goce de su derecho o libertad conculcado; es decir, la jurisprudencia de la Corte IDH condiciona el mínimo de efectividad de la norma convencional que deben aplicar las autoridades nacionales del Estado Parte para poder cumplir con sus obligaciones convencionales que derivan de los artículos $1^{\circ}$ y $2^{\circ}$ del Pacto de San José, relacionado también con el principio pro personae contenido en el artículo 29 de la propia Convención Americana.

56. Así, en la Resolución de supervisión de cumplimiento de sentencia en el Caso Gelman, a que se refiere el presente voto razonado, se explicita la obligación de los Estados Parte de la Convención Americana sobre la vinculación de la "norma convencional interpretada" (res interpretata) como una de las manifestaciones en que puede desplegarse el "control de convencionalidad" en situaciones y casos en que el Estado concernido no ha sido parte material en el proceso internacional en que fue establecida determinada jurisprudencia interamericana. ${ }^{88}$ En ese sentido "por el solo hecho de ser parte en la Convención Americana, toda autoridad pública y todos sus órganos, incluidas las instancias democráticas, jueces y demás órganos vinculados a la administración de justicia en todos los niveles, están obligados por el tratado, por lo cual deben ejercer, en el marco de sus respectivas competencias

\footnotetext{
86 Como se desprende de los Considerandos 69, 71 y 72 de la Resolución de supervisión de cumplimiento de la Sentencia en el Caso Gelman Vs. Uruguay, a que se refiere el presente voto razonado.

87 Sin menoscabo de las importantes atribuciones de la Comisión Interamericana de Derechos Humanos, como uno los dos órganos de protección del Sistema Interamericano, si bien su función principal es la de promover la observancia y la defensa de los derechos humanos, en términos del artículo 41 del propio Pacto de San José.

88 Cfr. Considerandos 67, 69 y 72 de la Resolución de supervisión de cumplimiento de la Sentencia en el Caso Gelman Vs. Uruguay, a que se refiere el presente voto razonado.
} 
y de las regulaciones procesales correspondientes, un control de convencionalidad tanto en la emisión y aplicación de normas, en cuanto a su validez y compatibilidad con la Convención, como en la determinación, juzgamiento y resolución de situaciones particulares y casos concretos, teniendo en cuenta el propio tratado y, según corresponda, los precedentes o lineamientos jurisprudenciales de la Corte Interamericana" 89

57. En el Caso Gelman no estamos en esta situación, debido a que al existir sentencia internacional con carácter de autoridad de cosa juzgada, produce una vinculación total y absoluta a la Sentencia, por lo que todas las autoridades del Estado uruguayo -incluyendo a sus jueces en todos los niveles- deben aplicar de manera "directa" los contenidos, fundamentos y efectos de la Sentencia (véase supra párrs. 34 a 42); siendo el "control de convencionalidad" un instrumento útil, efectivo y necesario para lograrlo y de ahí la relación existente entre esta institución con la autoridad de la "cosa juzgada internacional" (véase infra párrs. 80 a 100).

58. Sobre la eficacia de la jurisprudencia interamericana, fueron motivo de reflexiones en el voto razonado que emitimos a una sentencia derivada de un caso contencioso anterior: ${ }^{90}$

51. El juez nacional, por consiguiente, debe aplicar la jurisprudencia convencional incluso la que se crea en aquellos asuntos donde no sea parte el Estado nacional al que pertenece, ya que lo que define la integración de la jurisprudencia de la Corte IDH es la interpretación que ese Tribunal Interamericano realiza del corpus juris interamericano con la finalidad de crear un estándar en la región sobre su aplicabilidad y efectividad. ${ }^{91}$ Lo anterior lo consideramos de la mayor importancia para el sano entendimiento del "control difuso de convencionalidad", pues pretender reducir la obligatoriedad de la jurisprudencia convencional sólo a los casos donde el Estado ha sido "parte material", equivaldría a nulificar la esencia misma de la propia Convención

89 Considerando 69 de la Resolución de supervisión de cumplimiento de la Sentencia en el Caso Gelman Vs. Uruguay, a que se refiere el presente voto razonado.

90 Voto razonado emitido en el Caso Cabrera García y Montiel Flores vs. México. Excepciones Preliminares, Fondo, Reparaciones y Costas. Sentencia de 26 de noviembre de 2010, párrs. 51, 52 y 63.

91 De esta manera, por ejemplo, pueden formar parte de su jurisprudencia los estándares establecidos por la Corte Europea de Derechos Humanos, tratados internacionales del sistema universal, las resoluciones de los Comités de Naciones Unidas, las recomendaciones de la Comisión Interamericana de Derechos Humanos o incluso los informes de los relatores especiales de la OEA o de Naciones Unidas, entre otros, siempre y cuando la Corte IDH los utilice y los haga suyos para formar su interpretación del corpus juris interamericano y crear la norma convencional interpretada como estándar interamericano. 
Americana, cuyos compromisos asumieron los Estados nacionales al haberla suscrito y ratificado o adherido a la misma, y cuyo incumplimiento produce responsabilidad internacional.

52. Así, la "fuerza normativa" de la Convención Americana alcanza a la interpretación que de la misma realice la Corte IDH, como "intérprete última" de dicho Pacto en el Sistema Interamericano de Protección de los Derechos Humanos. La interpretación emprendida por el Tribunal Interamericano a las disposiciones convencionales adquiere la misma eficacia que poseen éstas, ya que en realidad las "normas convencionales" constituyen el resultado de la "interpretación convencional" que emprende la Corte IDH como órgano "judicial autónomo cuyo objetivo es la aplicación e interpretación"92 del corpus juris interamericano. Dicho en otras palabras, el resultado de la interpretación de la Convención Americana conforma la jurisprudencia de la misma; es decir, "constituyen normas que derivan de la $\mathrm{CADH}$, de lo cual se obtiene que gocen de la misma eficacia (directa) que tiene dicho tratado internacional".

63. No pasa inadvertido que el artículo 68.1 establece que los Estados parte del Pacto de San José "se comprometen a cumplir la decisión de la Corte en todo caso en que sean partes". Lo anterior no puede ser limitante para que la jurisprudencia de la Corte IDH adquiera "eficacia directa" en todos los Estados nacionales que han reconocido expresamente su jurisdicción, con independencia de que derive de un asunto donde no han participado formalmente como "parte material", ya que al ser la Corte IDH el órgano jurisdiccional internacional del Sistema Interamericano de Protección de Derechos Humanos, cuya función esencial es la aplicación e interpretación de la Convención Americana, sus interpretaciones adquieren el mismo grado de eficacia del texto convencional. En otras palabras, la norma convencional que deben aplicar los Estados es el resultado de la interpretación de las disposiciones del Pacto de San José (y sus protocolos adicionales, así como otros instrumentos internacionales). Las interpretaciones que realiza la Corte IDH se proyectan hacia dos dimensiones: (i) en lograr su eficacia en el caso particular con efectos subjetivos, y (ii) en establecer la eficacia general con efectos de norma interpretada. De ahí la lógica y necesidad de que el fallo, además de notificarse al Estado parte en la controversia particular, deba también ser "transmitido a los Estados parte de la Convención", ${ }^{93}$ para que tengan pleno conocimiento

\footnotetext{
92 Artículo $1^{\circ}$ del Estatuto de la Corte Interamericana de Derechos Humanos, aprobado por resolución núm. 448 de la Asamblea General de la OEA, en La Paz, Bolivia (octubre de 1979).

93 Artículo 69 de la Convención Americana sobre Derechos Humanos.
} 
del contenido normativo convencional derivado de la interpretación de la Corte IDH, en su calidad de "intérprete última" del corpus juris interamericano.

59. En ese sentido, un tema sobre el cual seguramente el Tribunal Interamericano tendrá en el futuro que reflexionar consiste en determinar si la "norma interpretada" alcanza eficacia erga omnes más allá de los "casos contenciosos" donde se produce la autoridad de la cosa juzgada; por ejemplo, en las "opiniones consultivas" donde no realiza una función "jurisdiccional" en sentido estricto, emitiendo una opinión interpretativa de la norma convencional, de otros tratados concernientes a la protección de los derechos humanos en los Estados americanos o incluso sobre la compatibilidad de leyes internas con aquéllos; ${ }^{94}$ con una amplia participación de todos los Estados de la OEA (y no sólo de la Convención Americana), incluso, con la posibilidad de realizar audiencias públicas, recibir amici curiae y aplicar por analogía las disposiciones del procedimiento escrito en casos contenciosos en lo que sean aplicables. ${ }^{95}$

60. Por otra parte, no debe perderse de vista que la eficacia interpretativa de la norma convencional ha sido resaltada desde hace tiempo por la doctrina europea con la denominación de "cosa interpretada" o chose interprétée, que en términos generales alude a la eficacia erga omnes que producen las sentencias del Tribunal de Estrasburgo hacia todos los Estados Parte en la Convención Europea que no intervinieron en el proceso internacional, en la medida en que el criterio interpretativo, como lo ha señalado el Tribunal Europeo de Derechos Humanos "sirve no sólo para decidir sobre los casos que conoce el Tribunal sino en general, para aclarar, proteger y desarrollar las normas previstas en la Convención" (Caso Irlanda contra el Reino Unido, de 18 de enero de 1978). ${ }^{96}$

94 Cfr. Artículos 64 de la Convención Americana y 70 a 73 del Reglamento de la Corte Interamericana de Derechos Humanos.

95 Cfr. Artículos 73 y 74 del Reglamento de la Corte Interamericana de Derechos Humanos.

96 En esta conocida sentencia se establece $(\$ 154)$ : "Nevertheless, the Court considers that the responsibilities assigned to it within the framework of the system under the Convention extend to pronouncing on the non-contested allegations of violation of Article 3 (art. 3). The Court's judgments in fact serve not only to decide those cases brought before the Court but, more generally, to elucidate, safeguard and develop the rules instituted by the Convention, thereby contributing to the observance by the States of the engagements undertaken by them as Contracting Parties (Article 19)" (Cursivas nuestras). Asimismo, véase la sentencia en el Caso Opuz contra Turquía de 2009 (\$163): “... gardant à l'esprit qu’elle a pour tâche de donner une interprétation authentique et définitive des droits et libertés énumérés dans le titre I de la Convention, la Cour doit déterminer si les autorités nationales ont dûment pris en compte des principes découlant des arrêts qu'elle a rendus sur des questions similaires, y compris dans des affaires concernant d'autres Etats". También véase la sentencia en el Caso Rantsev contra Chipre y Rusia (párr. 197): "Les arrêts de la Cour servent en effet 
61. Este "principio de solidaridad" -en los términos empleados por la Asamblea Parlamentaria del Consejo de Europa- que se ha venido consolidando en la jurisprudencia del Tribunal de Estrasburgo, fue incluso reconocido por aquel órgano en su importante resolución 1226 de 28 de septiembre de 2000 sobre la "Ejecución de las sentencias del Tribunal Europeo de Derechos Humanos": 97

3. El principio de solidaridad implica que la jurisprudencia de la Corte [Europea de Derechos Humanos] forma parte de la Convención, extendiendo asi la fuerza legalmente vinculante de la Convención erga omnes (a todas las otras Partes). Esto significa que los Estados Parte no sólo deben ejecutar las sentencias de la Corte pronunciadas en casos en que son parte, sino también deben tomar en consideración las posibles implicaciones que las sentencias pronunciadas en otros casos puedan tener en sus propios ordenamientos jurídicos y prácticas legales. (Cursivas nuestras).

62. El "principio de solidaridad", conjuntamente con la consolidada doctrina jurisprudencial del Tribunal de Estrasburgo sobre la vinculación a sus propios precedentes (por ejemplo, véase el Caso Mamatkoulov y Askarov contra Turquia), ${ }^{98}$ ha ido progresivamente generando convicción y práctica de los propios Estados sometidos a la jurisdicción del Tribunal a la hora de considerar obligatoria su jurisprudencia como parte de las obligaciones convencionales.

63. Incluso, el propio Tribunal de Estrasburgo se ha referido a la Convención Europea de Derechos Humanos como un instrument constitutionnel de l'ordre public

non seulement à statuer sur les affaires dont elle est saisie, mais plus généralement à clarifier, sauvegarder et étoffer les normes de la Convention, contribuant ainsi au respect par les États des engagements pris par eux en leur qualité de Parties contractantes" (\$197).

97 Nota 38 de la Resolución de supervisión de cumplimiento de la Sentencia en el Caso Gelman Vs. Uruguay, a que se refiere el presente voto razonado. El texto original puede verse en http://assembly.coe.int/ ASP/Doc/XrefViewPDF.asp?FileID=16834\&Language=EN "Execution of judgments of the European Court of Human Rights": "[...] ("3. The principle of solidarity implies that the case-law of the Court forms part of the Convention, thus extending the legally binding force of the Convention erga omnes (to all the other parties). This means that the states parties not only have to execute the judgments of the Court pronounced in cases to which they are party, but also have to take into consideration the possible implications which judgments pronounced in other cases may have for their own legal system and legal practice").

98 De febrero de 2005, \$ 121: "121. Sans que la Cour soit formellement tenue de suivre ses arrêts antérieurs, il est dans l'intérêt de la sécurité juridique et de la prévisibilité qu'elle ne s'écarte pas sans motif valable de ses propres précédents (voir, par exemple, mutatis mutandis, Chapman c. Royaume-Uni [GC], no 27238/95, $\$ 70$, CEDH 2001-I, et Christine Goodwin c. Royaume-Uni [GC], no 28957/95, \$ 74, CEDH 2002-VI). Cependant, il est d'une importance cruciale que la Convention soit interprétée et appliquée d'une manière qui en rende les garanties concrètes et effectives et non pas théoriques et illusoires. En outre, elle est un instrument vivant à interpréter à la lumière des conditions actuelles (voir, par exemple, Tyrer c. Royaume-Uni, arrêt du 25 avril 1978, série A no 26, pp. 15-16, \$31, et Christine Goodwin, précité, \$ 75)”. 
européen. ${ }^{99}$ De ahí que se hable -cada vez con mayor frecuencia- en el seno de la Asamblea Parlamentaria del Consejo de Europa, de la autoridad interpretativa de las sentencias del Tribunal Europeo de Derechos Humanos; ${ }^{100}$ incluso como una necesidad apremiante ante el incremento del número de casos desde que existe acceso directo al Tribunal de Estrasburgo al desaparecer la Comisión por el Protocolo 11 del Convenio Europeo.

64. En este sentido, cabe destacar el reciente voto concurrente del Juez Paulo Pinto de Albuquerque de Portugal, en el Caso Fabris contra Francia de febrero de 2013, donde reflexiona sobre L'effet direct et erga omnes des arrêts de la Cour:101

El efecto directo y erga omnes de las sentencias de la Corte. A primera vista, el Convenio establece que los efectos de las sentencias de la Corte se limitan a las partes en el caso, es decir, al solicitante (s) y al Estado o a los Estados demandados. Esta primera lectura es engañosa, y requiere de una correcta interpretación del artículo 46 leído conjuntamente con el artículo 1. A la luz de esas disposiciones, leídas conjuntamente, las sentencias de la Corte tienen un efecto directo y erga omnes.

65. En una de sus notas al pie de página del referido voto, se hace referencia a una cita del antiguo presidente del Tribunal de Estrasburgo, que señala que "la autoridad de la cosa interpretada por la Corte va más allá de la res judicata en sentido estricto". 102 Expresión sobre la "cosa interpretada" que el Tribunal de Estrasburgo en 2010 recoge en la sentencia del Caso Taxquet contra Bélgica citando a la Cour de Cassation belga. ${ }^{103}$

99 Cfr. Caso Loizidou contra Turquía, Grand Chambe, 23 de marzo de 1995, excepciones preliminares, $\$ 75$.

100 Por ejemplo, cfr. Committee on Legal Affairs and Human Rights. Contribution to the Conference on the Principle of Subsidiarity, Skopje, 1-2 October 2010: "Strengthening Subsidiarity: Integrating the Strasbourg Court's Case law into National Law and Judicial Practice". Puede consultarse en www.assembly.coe.int/... /2010/20101125_skopje.pdf.

101 Grande Chambre, Affaire Fabris c. France (Requête no 16574/08), Sentencia de fondo, 7 de febrero de 2013, p. 28.

102 Ibidem, p. 29, nota al pie de página 6:: “... L'autorité de la chose interprétée par la Cour va au-delà de la res judicata au sens strict. Une telle évolution ira de pair avec l'« effet direct » de la Convention en droit interne et avec son appropriation par les Etats. » Cette idée, inscrite au point 4 c) de la Déclaration d'Interlaken, constitue la pratique des Etats parties (Avis de la Commission de Venise, précité, \$ 32)”. (Cursivas nuestras).

103 Grande Chambre, Affaire Taxquet c. Belgique (Requête no 926/05), Sentencia de 16 de noviembre de $2010, \$ 33$. 
66. No debe pasar inadvertido que en el Sistema Interamericano existe una obligación no prevista explícitamente en la Convención de Roma -claramente identificable en el Pacto de San José- como es la necesidad de "adoptar disposiciones de derecho interno" (medidas legislativas o de otro carácter) para lograr la efectividad de los derechos y libertades, que establece el artículo $2^{\circ}$ de la Convención Americana en los términos analizados (véase supra párrs. 4450).

C.3) Diferencia en los alcances y grado de vinculación entre la eficacia subjetiva de la sentencia "interpartes" y la eficacia objetiva de la sentencia "erga omnes"

67. En los epígrafes anteriores se analizó la eficacia de la sentencia en dos dimensiones: hacia las partes que intervinieron en el proceso internacional (res judicata); y hacia todos los Estados Parte de la Convención Americana (res interpretata). En ambos casos se produce una "eficacia vinculante" si bien difieren cualitativamente.

68. Cuando existe una sentencia interamericana que involucra la responsabilidad internacional de un Estado en concreto, se produce una eficacia vinculante directa, completa y absoluta por parte de las autoridades nacionales de cumplir en sus términos con el fallo, incluyendo las rationes decidendi (véase supra párrs. 34-42), debido a lo establecido en los artículos 67 y 68.1 de la Convención Americana y de la "autoridad de cosa juzgada" (material y sustancial) que adquiere la sentencia.

69. En cambio, diversa eficacia de vinculación produce la sentencia interamericana para los demás Estados Parte que no intervinieron en el proceso internacional, al sólo limitarse a la "jurisprudencia interamericana", es decir, a la "norma convencional interpretada" y no así a la totalidad del fallo. Esta eficacia interpretativa es "relativa", en la medida en que se produce siempre y cuando no exista una interpretación que otorgue mayor efectividad a la norma convencional en el ámbito nacional. Esto es así, ya que las autoridades nacionales pueden ampliar el estándar interpretativo; incluso, pueden dejar de aplicar la norma convencional cuando exista otra norma nacional o internacional que amplíe la efectividad del derecho o libertad en juego, en términos del artículo 29 de la Convención Americana. Además, deben considerarse las reservas, declaraciones interpretativas y denuncias en cada caso, si bien en esos supuestos 
la Corte IDH puede, eventualmente, pronunciarse sobre su validez y adecuada interpretación, ${ }^{104}$ como lo ha realizado en algunas ocasiones. ${ }^{105}$

70. Para el debido cumplimiento de la Sentencia en el Caso Gelman, el Tribunal Interamericano consideró necesario explicitar el diverso grado de eficacia que producen las sentencias interamericanas, dependiendo si el Estado Parte de la Convención ha sido parte material en el proceso internacional. ${ }^{106}$ Lo anterior es fundamental para distinguir la "eficacia vinculante" que adquiere el fallo para el Estado uruguayo, que comprende la sentencia en su integridad -res judicata(véase supra párrs. 34 a 42); de la diversa "eficacia vinculante" indirecta derivada de la misma Sentencia y proyectada hacia todos los Estados Parte de la Convención Americana -res interpretata- (véase supra párrs. 43 a 66).

71. En la primera no existe posibilidad de interpretación de la norma convencional, en la medida en que todos los órganos, poderes y autoridades del Estado del Uruguay quedan vinculados en su integridad por la Sentencia del Caso Gelman, precisamente porque el Estado uruguayo participó en calidad de "parte material" en la controversia internacional. Existe una eficacia vinculante directa, completa y absoluta de la sentencia internacional, incluyendo su parte considerativa como ya se estableció. De ahí que el Estado no puede invocar una norma o interpretación constitucional para dejar de cumplir con la sentencia internacional, debido a las obligaciones convencionales previstas en el artículo 68.1 de la Convención Americana, en relación con los preceptos 26 y 27 de la Convención de Viena

$104 \mathrm{La}$ Corte IDH ha establecido que "una reserva que suspenda todo el derecho fundamental cuyo contenido es inderogable debe ser considerado como incompatible con el objeto y el propósito de la Convención y, consecuentemente, incompatible con la misma. La situación podría ser diferente si la reserva solamente restringe ciertos aspectos del derecho interno inderogable sin privar al derecho de su contenido básico" (Caso Radilla Pacheco Vs. México. Excepciones Preliminares, Fondo, Reparaciones y Costas. Sentencia de 23 de Noviembre de 2009. Serie C No 209, párr. 310. Al realizar esta determinación el Tribunal debe examinar si aun cuando la reserva sólo restringe algunos aspectos de un derecho inderogable, ésta impide darle pleno sentido y efecto útil al tratado. Cfr. Restricciones a la Pena de Muerte (Arts. 4.2 y 4.4 Convención Americana sobre Derechos Humanos). Opinión Consultiva OC-3/83 del 8 de septiembre de 1983. Serie A No 3, párr. 61; y Caso Velásquez Rodríguez Vs. Honduras. Excepciones Preliminares. Sentencia de 26 de junio de 1987. Serie C No 1, párr. 30 .

105 Cfr., por ejemplo, Caso Radilla Pacheco Vs. México. Excepciones Preliminares, Fondo, Reparaciones y Costas. Sentencia de 23 de noviembre de 2009. Serie C No 209, párrs. 311 y 312.

106 Cfr. Considerando 67 de la Resolución de supervisión de sentencia del Caso Gelman Vs. Uruguay, a que se refiere el presente voto razonado. 
sobre el Derecho de los Tratados, incluso cuando conoce y resuelve un medio de "control de constitucionalidad". 107

72. En cambio, la Sentencia del Caso Gelman produce una eficacia vinculante de la jurisprudencia interamericana hacia los demás Estados Parte de la Convención Americana. Eficacia que se proyecta sólo en cuanto al estándar mínimo de interpretación de la norma convencional para asegurar el mínimo de efectividad de la misma; lo cual, como ya se estableció (véase supra párr. 69), es una eficacia vinculante "relativa" en la medida en que puede diferir de la jurisprudencia de la Corte IDH cuando se efectivice la norma a través de una interpretación más favorable en sede nacional. En ese sentido, existe un "margen interpretativo nacional" que pueden realizar las autoridades para favorecer con la interpretación nacional la efectividad del derecho o libertad fundamental, siempre y cuando sea para potencializar la efectividad de la norma convencional; circunstancia que no aplica cuando un Estado fue "parte material" en el proceso internacional, quedando vinculado de manera íntegra al fallo en todos sus aspectos, debido a los alcances de la autoridad de la cosa juzgada internacional.

73. En el Sistema Europeo de Protección de Derechos Humanos existe una obligación de los Estados Parte de cumplir con la sentencia. La "fuerza obligatoria y ejecución de sentencias" deriva de manera expresa del artículo 46.1 y 2 del Convenio Europeo de Derechos Humanos. ${ }^{108}$ Aquí se advierte otra de las

107 La Suprema Corte de Justicia del Uruguay estimó que: "Por ello, lo sustentado en el fallo internacional referido [Sentencia del Caso Gelman vs. Uruguay] no consigue alterar los parámetros preceptivos sobre los cuales corresponde resolver la cuestión de inconstitucionalidad de autos (arts. 256 a 259 de la Carta). Y se agrega que "Abundando en el tema, reiteran, en el caso a estudio la cuestión a resolver dice relación -exclusiva- con la comprobación o no de la adecuación de la norma legal a los derechos y garantías consagrados en la Constitución Nacional. Y sólo al órgano jerarca del Poder Judicial es a quien corresponde efectuar ese juicio de comprobación”. Sentencia No 20 de 22 de febrero de 2013, pp. 18 y 19.

108 "Artículo 46. Fuerza obligatoria y ejecución de las sentencias 1. Las Altas Partes Contratantes se comprometen a acatar las sentencias definitivas del Tribunal en los litigios en que sean partes. 2. La sentencia definitiva del Tribunal se transmitirá al Comité de Ministros, que velará por su ejecución. 3. Cuando el Comité de Ministros considere que la supervisión de la ejecución de una sentencia definitiva resulta obstaculizada por un problema de interpretación de dicha sentencia, podrá dirigirse al Tribunal con objeto de que éste se pronuncie sobre dicho problema de interpretación. La decisión de dirigirse al Tribunal se tomará por mayoría de dos tercios de los votos de los representantes que tengan derecho a formar parte del Comité. 4. Si el Comité considera que una Alta Parte Contratante se niega a acatar una sentencia definitiva sobre un asunto en que es parte, podrá, tras notificarlo formalmente a esa Parte y por decisión adoptada por mayoría de dos tercios de los votos de los representantes que tengan derecho a formar parte del Comité, plantear al Tribunal la cuestión de si esa Parte ha incumplido su obligación en virtud del párrafo 1. 5. Si el Tribunal concluye que se ha producido una violación del párrafo 1, remitirá el asunto al Comité de Ministros para que examine 
trascendentales diferencias con el Sistema Interamericano, en la medida en que no es el Tribunal Europeo de Derechos Humanos el encargado de hacer cumplir sus fallos, sino que lo es el Comité de Ministros, como órgano político, el que tiene la competencia de la supervisión de las sentencias. En ese sentido, el Comité de Ministros puede solicitar la intervención del Tribunal de Estrasburgo para que se pronuncie cuando exista un obstáculo en la ejecución de la sentencia definitiva derivado de un problema de interpretación del fallo. ${ }^{109}$

74. Cuando la Corte IDH supervisa el cumplimiento de una sentencia, como lo está haciendo ahora en el Caso Gelman, puede también advertir que existen obstáculos en su cumplimiento debido a una inadecuada interpretación en sede nacional de la Convención Americana, de la propia Sentencia o, en general, del corpus juris interamericano. Pareciera que ese es el caso de la sentencia de 22 de febrero de 2013 de la Suprema Corte de Justicia del Uruguay, que le imprime distintas interpretaciones y alcances al fallo de la Corte IDH; y es por ello que en la Resolución de supervisión a que se refiere el presente voto razonado, se precisan y enfatizan los alcances interpretativos de la Sentencia en el Caso Gelman, la manera en que el fallo de la Suprema Corte de Justicia del Uruguay constituye "un obstáculo para el pleno acatamiento de la Sentencia", ${ }^{110}$ lo que podría producir "un quebrantamiento al acceso a la justicia de las víctimas de graves violaciones de derechos humanos que se encuentran amparadas por una sentencia de la Corte Interamericana y podría representar un instrumento de perpetuación de la impunidad y el olvido de esos hechos". ${ }^{111}$

\section{D) Eficacia objetiva de la sentencia como parte del sistema de "garantía colectiva"}

75. También se produce una relación directa entre la eficacia de la sentencia (consecuencia de la cosa juzgada internacional) y el sistema de "garantía colectiva" derivada de la propia Convención Americana. Todos los Estados Parte del Pacto

las medidas que sea preciso adoptar. En caso de que el Tribunal concluya que no se ha producido violación alguna del párrafo 1, reenviará el asunto al Comité de Ministros, que pondrá fin a su examen del asunto.

109 Cfr. Art. 46.3 del Convenio Europeo de Derechos Humanos.

110 Cfr. punto Resolutivo 2 de la Resolución de supervisión de cumplimiento de Sentencia en el Caso Gelman Vs. Uruguay, a que se refiere el presente voto razonado.

111 Considerando 102, in fine, de la Resolución de supervisión de cumplimiento de Sentencia en el Caso Gelman Vs. Uruguay, a que se refiere el presente voto razonado. 
se encuentran obligados, en su conjunto, a lograr el cumplimiento y eficacia de los pronunciamientos que emite el Tribunal Interamericano en tanto que los Estados Parte de la Convención y, en general, todos los Estados que conforman la Organización de Estados Americanos, se encuentran interesados en coadyuvar en el establecimiento de un orden público interamericano que garantice el desarrollo democrático de los pueblos. La Convención Americana establece la posibilidad de garantizar el cumplimiento de las sentencias del Tribunal Interamericano en términos del artículo 65 del Pacto de San José.

76. En este sentido, cobran vigencia las acertadas palabras del antiguo presidente de la Corte Interamericana de Derechos Humanos, Antônio Augusto Cançado Trindade, pronunciadas hace más de una década ante el Consejo Permanente de la OEA: 112

El ejercicio de la garantía colectiva por los Estados Partes en la Convención no debería ser sólo reactivo, cuando se produjera el incumplimiento de una sentencia de la Corte, sino también proactivo, en el sentido de que todos los Estados Partes adoptaran previamente medidas positivas de protección en conformidad con la normativa de la Convención Americana. Es indudable que una sentencia de la Corte es 'cosa juzgada', obligatoria para el Estado demandado en cuestión, pero también es 'cosa interpretada', válida erga omnes partes, en el sentido de que tiene implicaciones para todos los Estados Partes en la Convención, en su deber de prevención. Sólo mediante un claro entendimiento de esos puntos fundamentales lograremos construir un ordre public interamericano basado en la fiel observancia de los derechos humanos. (Cursivas nuestras).

77. En efecto, el Tribunal Interamericano ha señalado que los propios Estados Americanos han dispuesto un "sistema de garantía colectiva" que significa que los Estados Parte del Pacto de San José deben procurar todos los esfuerzos para que abonen al cumplimiento de las sentencias de la Corte IDH. Así, ha señalado que: ${ }^{113}$

11217 de abril de 2012, reproducido dos días después en la Sesión de la Comisión de Asuntos Jurídicos y Políticos, celebrada el 19 de abril de 2012, con motivo de la presentación que como Presidente de la Corte Interamericana de Derechos Humanos realizó en la reunión conjunta de la Corte IDH y la Comisión Interamericana de Derechos Humanos. Presentación denominada "Hacia la consolidación de la capacidad jurídica internacional de los peticionarios en el Sistema Interamericano de Protección de los Derechos Humanos".

113 Supervisión de Cumplimiento de Sentencia. Resolución de la Corte Interamericana de Derechos Humanos de 23 de noviembre de 2012. Caso Apitz Barbera y otros ("Corte Primera de lo Contencioso Administrativo") Vs. Venezuela, Considerandos 46 y 47. 
46. El importante rol de la noción de garantía colectiva para la implementación de las decisiones internacionales de órganos de derechos humanos ha sido resaltada en otros casos emitidos por esta Corte ${ }^{114}$, por el Comité de los Derechos Humanos ${ }^{115}$ y por el Tribunal Europeo de Derechos Humanos ${ }^{116}$. La noción de garantía colectiva también ha sido utilizada por el Comité de Ministros del Consejo de Europa al valorar el incumplimiento de algunas sentencias ${ }^{117}$ y constituye uno de los fundamentos de la enmienda del artículo 46 del Convenio Europeo de Derechos Humanos, establecida en 2009 con el objeto de fortalecer el mecanismo de supervisión e implementación de las sentencias a través de la asignación de nuevas facultades al Comité de Ministros y al Tribunal Europeo ${ }^{118}$.

114 "Al respecto, en casos contenciosos como Goiburú y otros Vs. Paraguay, La Cantuta Vs. Perú, y Masacre de Mapiripán Vs. Colombia, la Corte ha aplicado este concepto para establecer que los Estados Partes en la Convención deben colaborar entre sí para erradicar la impunidad de las violaciones cometidas en estos casos, mediante el juzgamiento y, en su caso, sanción de sus responsables. En consecuencia, la Corte declaró que el mecanismo de garantía colectiva establecido bajo la Convención Americana, en conjunto con las obligaciones internacionales regionales y universales en la materia, vinculaban a los Estados de la región a colaborar de buena fe en ese sentido, ya sea mediante la extradición o el juzgamiento en su territorio de los responsables de los hechos de dichos casos".

115 "[T] odo Estado Parte tiene un interés jurídico en el cumplimiento por todos los demás Estados Partes de sus obligaciones. Esto se deduce del principio de que las normas relativas a los derechos básicos de la persona humana' son obligaciones erga omnes y que, como se indica en el párrafo cuarto del preámbulo del Pacto, existe una obligación estipulada en la Carta de las Naciones Unidas de promover el respeto universal y la observancia de los derechos humanos y las libertades fundamentales". Observación General No 31, Comentarios generales adoptados por el Comité de los Derechos Humanos, La índole de la obligación jurídica general impuesta, $80^{\circ}$ período de sesiones, U.N. Doc. HRI/GEN/1/Rev.7 at 225 (2004), párr. 2".

116 "A diferencia de los tratados internacionales del tipo clásico, la Convención comprende más que simples compromisos recíprocos entre los Estados Partes. Crea, por encima de un conjunto de compromisos bilaterales, mutuos, obligaciones objetivas que, en los términos del Preámbulo, cuentan con una 'garantía colectiva”. TEDH, Caso Irlanda Vs. Reino Unido (No. 5310/71), Sentencia de 18 de enero de 1978, párr. 239. En igual sentido, TEDH, Caso Mamatkulov y Askarov Vs. Turquia (Nos. 46827/99 y 46951/99), Sentencia de 4 de febrero de 2005, párr. 100. Igualmente, en el caso Soering Vs. Reino Unido, el Tribunal Europeo declaró que la Convención Europea debe ser interpretada "en función de su carácter específico de tratado de garantía colectiva de derechos humanos y libertades fundamentales. [...] De este modo, el objeto y fin de la Convención como instrumento de protección de seres humanos exigen interpretar y aplicar sus disposiciones de manera que dicha protección sea práctica y efectiva”. TEDH, Caso Soering Vs. Reino Unido (No 14038/88), Sentencia de 7 de julio de 1989, párr. 87. De igual forma, TEDH, Caso lhan Vs. Turquía (No 22277/93), Sentencia de 27 de junio de 2000, párr. 51; Caso Glasenapp Vs. Alemania (No 9228/80), Sentencia de 28 de agosto de 1986, párr. 48, y Caso Shamayev y otros Vs. Georgia y Rusia (№ 36378/02), Sentencia de 12 de abril de 2005. Final, 12 de octubre de 2005, párr. 302".

117 “TEDH, Caso Loizidou Vs. Turquía (No 15317/89), Sentencia de 23 de marzo de 1995 y Consejo de Europa, Comité de Ministros, Resolución (Res. DH (2001) 80) respecto a la sentencia del Tribunal Europeo de Derechos Humanos de 28 de julio de 1998 en el caso Loizidou Vs. Turquía, adoptada por el Comité de Ministros el 26 de junio de 2001".

118 "Los Estados Parte de la Convención tienen el deber colectivo de preservar la autoridad de la Corte -y por tanto la credibilidad y efectividad del sistema de la Convención-, siempre que el Comité de Ministros 
47. Al respecto, este Tribunal ha señalado que la Convención Americana, así como los demás tratados de derechos humanos, se aplican de conformidad con la noción de garantía colectiva y tienen una naturaleza especial, que los diferencian de los demás tratados, los cuales reglamentan intereses recíprocos entre los Estados Partes ${ }^{119}$. Dicha noción de garantía colectiva se encuentra estrechamente relacionada con el efecto útil de las Sentencias de la Corte Interamericana, por cuanto la Convención Americana consagra un sistema que constituye un verdadero orden público regional, cuyo mantenimiento es de interés de todos y cada uno de los Estados Partes. El interés de los Estados signatarios es el mantenimiento del sistema de protección de los derechos humanos que ellos mismos han creado, y si un Estado viola su obligación de acatar lo resuelto por el único órgano jurisdiccional sobre la materia se está quebrantando el compromiso asumido hacia los otros Estados de cumplir con las sentencias de la Corte. Por tanto, la labor de la Asamblea General de la Organización de los Estados Americanos cuando se le presenta un incumplimiento manifiesto por parte de uno de los Estados de una Sentencia emitida por la Corte Interamericana, es precisamente la de proteger el efecto útil de la Convención Americana y evitar que la justicia interamericana se torne ilusoria al quedar al arbitrio de las decisiones internas de un Estado. (Cursivas nuestras).

78. Evidentemente, no estamos en ese supuesto en la Resolución de supervisión de cumplimiento de sentencia que motiva el presente voto razonado. Por el contrario, la Corte IDH ha valorado el esfuerzo y las acciones realizadas por el Estado uruguayo en el cumplimiento de la Sentencia en el Caso Gelman;120 y ha dado por satisfactoriamente cumplidos aspectos muy importantes del fallo (véase supra párrs. 4 y 5). ${ }^{121}$ Asimismo, ha considerado relevante "determinadas acciones dirigidas al cumplimiento de los puntos resolutivos 9 y 11 de la Sentencia" (véase supra párrs. 6 y 7); ${ }^{122}$ advirtiendo también del "obstáculo" para el pleno

considere que uno de los Estados Parte se rehúsa a cumplir, de manera expresa o a través de su conducta, con la Sentencia emitida por la Corte en un caso en el cual es parte". Consejo de Europa, Comité de Ministros, Exposición de motivos del Protocolo 14 al Convenio Europeo. Disponible en: http://conventions.coe.int/ Treaty/EN/Reports/Html/194.htm".

119 Cfr. Caso Baena Ricardo y otros Vs. Panamá. Competencia, párr. 96.

120 Considerandos 8, 12, 13, 27, 42, 43, 44, 45, 46, 103 y Punto Declarativo 2 de la Resolución de supervisión de cumplimiento de la Sentencia en el Caso Gelman Vs. Uruguay, a que se refiere el presente voto razonado.

121 Resolutivo 1 de la Resolución de supervisión de cumplimiento de la Sentencia en el Caso Gelman Vs. Uruguay, a que se refiere el presente voto razonado.

122 Cfr. Resolutivo 2 de la Resolución de supervisión de cumplimiento de sentencia en el Caso Gelman vs. Uruguay, a que se refiere el presente voto razonado. 
cumplimiento de la Sentencia que supone el fallo de 22 de febrero de 2013 de la Suprema Corte de Justicia del Uruguay (véase supra párrs. 8 y 9). ${ }^{123}$

79. En ese sentido, debe destacarse la buena voluntad del Estado del Uruguay para cumplir sus obligaciones internacionales, lo cual se advierte, además, al haber admitido parcialmente la responsabilidad internacional durante el proceso internacional, ${ }^{124}$ teniendo "un alto valor simbólico en aras de que no se repitan hechos similares". ${ }^{125}$

\section{Autoridad DE LA “COSA JUZGADA INTERNACIONAL” Y "CONTROL DE CONVENCIONALIDAD"}

80. Cuando se produce autoridad de la cosa juzgada internacional debido a la firmeza de la sentencia de la Corte IDH -que implica su carácter "inmutable"existe una eficacia directa y subjetiva de la sentencia (res judicata) hacia las partes en su integridad (véase supra párrs. 34 a 42); y una eficacia interpretativa objetiva e indirecta de la norma convencional (res interpretata) hacia todos los Estados Parte de la Convención Americana (véase supra párrs. 43 a 66).

81. En la presente Resolución de supervisión de cumplimiento de sentencia, el Tribunal Interamericano realiza una distinción para efectos del adecuado ejercicio del "control de convencionalidad" en sede nacional de la mayor trascendencia para el Sistema Interamericano "dependiendo de si la Sentencia ha sido dictada en un caso en el cual el Estado ha sido parte o no. Lo anterior debido a que la norma convencional interpretada y aplicada adquiere distinta vinculación dependiendo si el Estado fue parte material o no en el proceso internacional". ${ }^{126}$

82. Esto implica dos manifestaciones distintas en el ejercicio del "control de convencionalidad" en sede nacional que involucra directamente a las partes que intervinieron en el proceso internacional (res judicata); y de manera indirecta a todas las autoridades de los Estados Parte de la Convención Americana (res interpretata).

\footnotetext{
123 Cfr. Idem.

124 Caso Gelman Vs. Uruguay. Fondo y Reparaciones. Sentencia de 24 de febrero de 2011. Serie C No 221, párrs. 19-31.

125 Caso Gelman Vs. Uruguay. Fondo y Reparaciones. Sentencia de 24 de febrero de 2011. Serie C No 221, párr. 30.

126 Párr. 67 de la Resolución de supervisión de cumplimiento de Sentencia en el Caso Gelman Vs. Uruguay, a que se refiere el presente voto razonado.
} 


\section{A) Res judicata y "control de convencionalidad"}

83. Cuando en una sentencia de la Corte IDH se ha determinado la responsabilidad internacional de un Estado, la autoridad de la cosa juzgada produce, necesariamente, vinculación absoluta en la manera en que las autoridades nacionales del Estado condenado deben interpretar la norma convencional y, en general, el corpus juris interamericano aplicado en la sentencia que decide el caso. Esto significa que todos los órganos, poderes y autoridades del Estado concernido -legislativas, administrativas y jurisdiccionales en todos los niveles-, se encuentran obligadas por la sentencia internacional en sus términos, incluyendo los fundamentos, consideraciones, resolutivos y efectos que produce.

84. En ese supuesto, el "control de convencionalidad" constituye una herramienta útil, adecuada y necesaria para lograr el cumplimiento y debida implementación de la sentencia internacional, en la medida en que esta institución permite aplicar no sólo el Derecho Internacional y particularmente el Derecho Internacional de los Derechos Humanos, sino también posibilita cumplir con la obligación internacional derivada de la sentencia interamericana de conformidad con el artículo 68.1 de la Convención Americana. Lo anterior adquiere especial relevancia cuando el cumplimiento de la sentencia internacional implica "dejar sin efectos" una norma general, en tanto que todas las autoridades y con mayor razón las que realizan funciones jurisdiccionales -en todos los niveles- "tienen la función de hacer prevalecer la Convención Americana y los fallos de esta Corte sobre la normatividad interna, interpretaciones y prácticas que obstruyan el cumplimiento de lo dispuesto en un determinado caso". 127

85. De ahí se deriva la importancia que adquiere un adecuado ejercicio y entendimiento del "control de convencionalidad" para el debido cumplimiento de una sentencia interamericana. En la Sentencia del Caso Gelman, al haberse declarado por la Corte IDH "sin efectos" la Ley de Caducidad de la Pretensión Punitiva del Estado (Ley No 15.848), 128 todas las autoridades uruguayas -incluyendo

127 Párr. 73 de la Resolución de supervisión de cumplimiento de Sentencia en el Caso Gelman Vs. Uruguay, a que se refiere el presente voto razonado.

128 Por ser contraria a la Convención Americana y a la Convención Interamericana sobre Desaparición Forzada de Personas. En el Resolutivo 6 de la Sentencia se declaró que el Estado incumplió la obligación de adecuar su derecho interno a la Convención Americana (contenido en el art. 2, en relación con los artículos 8.1, 25 y 1.1 de la misma y con los artículos I.b, III, IV y V de la Convención Interamericana sobre Desaparición Forzada de Personas), como consecuencia de la interpretación y aplicación que le ha dado a la Ley de Caducidad Punitiva del Estado respecto de graves violaciones de derechos humanos. 
sus jueces en todos los niveles- deben "garantizar" que dicha norma no vuelva a representar un obstáculo para la investigación de los hechos, juzgamiento y, si procede, sanción de los responsables de las víctimas del Caso Gelman, así como de otros casos de violaciones graves de derechos humanos acontecidos en Uruguay en el periodo de la dictadura militar (1973-1985). Lo anterior, debido a que:

231. La falta de investigación de las graves violaciones de derechos humanos cometidas en este caso, enmarcadas en patrones sistemáticos, revelan un incumplimiento de las obligaciones internacionales del Estado, establecidas por normas inderogables ${ }^{129}$.

232. Dada su manifiesta incompatibilidad con la Convención Americana, las disposiciones de la Ley de Caducidad que impiden la investigación y sanción de graves violaciones de derechos humanos carecen de efectos jurídicos $\mathrm{y}$, en consecuencia, no pueden seguir representando un obstáculo para la investigación de los hechos del presente caso y la identificación y el castigo de los responsables, ni pueden tener igual o similar impacto respecto de otros casos de graves violaciones de derechos humanos consagrados en la Convención Americana que puedan haber ocurrido en el Uruguay ${ }^{130}$. (Cursivas nuestras).

86. Las autoridades y especialmente los jueces uruguayos que estén investigando las violaciones graves a los derechos humanos durante el período de dictadura militar (1973-1985), tienen la obligación, para poder cumplir con la sentencia interamericana, de aplicar directamente las consideraciones que la fundamentan. En este sentido, las rationes decidendi que fundamentan los puntos resolutivos de la Sentencia del Caso Gelman resultan indispensables para su adecuado entendimiento y lograr el debido, efectivo e íntegro cumplimiento de la misma.

87. Lo anterior significa que para el adecuado ejercicio del control de convencionalidad ex officio, las autoridades y especialmente los jueces uruguayos de todos los niveles, deben considerar, en términos de la Sentencia internacional donde la República Oriental del Uruguay fue parte material y, por tanto, obliga en sus términos:

(i) que la Ley de Caducidad fue declarada "sin efectos jurídicos" por su incompatibilidad con la Convención Americana y la Convención Interamericana sobre

129 Cfr. Caso Goiburú y otros, supra nota 23, párrs. 93 y 128; Caso Ibsen Cárdenas e Ibsen Peña, supra nota 9, párrs. 61 y 197, y Caso Gomes Lund y otros (Guerrilha do Araguaia), supra nota 16, párr. 137.

130 Cfr. Caso Barrios Altos. Fondo, supra nota 288, párr. 44; Caso La Cantuta Vs. Perú. Fondo, Reparaciones y Costas. Sentencia de 29 de noviembre de 2006. Serie C No 162, párr. 175, y Caso Gomes Lund y otros (Guerrilha do Araguaia), supra nota 16, párr. 174. 
Desaparición Forzada de Personas, en cuanto puede impedir la investigación y eventual sanción de los responsables de graves violaciones de derechos humanos en el Caso Gelman y de otros casos de graves violaciones de derechos humanos ocurridos en Uruguay en el mismo período; ${ }^{131}$

(ii) que los efectos de la Ley de Caducidad o de normas análogas, como las de prescripción, caducidad, irretroactividad de la ley penal u otras excluyentes similares de responsabilidad o cualquier interpretación administrativa o judicial al respecto, no se constituyan en un impedimento u obstáculo para continuar las investigaciones; ${ }^{132}$

(iii) que la sentencia de la Suprema Corte de Justicia del Uruguay de 22 de febrero de 2013 "constituye un obstáculo para el pleno acatamiento de la Sentencia" del Caso Gelman;133

(iv) que las violaciones graves a los derechos humanos-como lo es la desaparición forzada de personas, entre otras- resultan "imprescriptibles" al constituir, por su propia naturaleza, una violación de normas jus cogens, amparadas en normas de derecho internacional de carácter inderogable;134

(v) que la desaparición forzada de personas constituye un delito permanente o continuado; 135

(vi) que el Caso Gelman "es un caso de graves violaciones de derechos humanos, en particular desapariciones forzadas, por lo que es ésta la tipificación que debe primar en las investigaciones que corresponda abrir o continuar a nivel interno. Como ya se ha establecido, por tratarse de un delito de ejecución permanente, es decir, cuya consumación se prolonga en el tiempo, al entrar en vigor la tipificación

131 Cfr. Caso Gelman Vs. Uruguay. Fondo y Reparaciones. Sentencia de 24 de febrero de 2011. Serie C No 221, párrs. 246, 253 y punto Resolutivo 11.

132 Cfr. Caso Gelman Vs. Uruguay. Fondo y Reparaciones. Sentencia de 24 de febrero de 2011. Serie C No 221, párr. 254 y Considerando 104 de la Resolución de la Corte Interamericana de 20 de marzo de 2013, relativa a la supervisión de cumplimiento de sentencia del Caso Gelman Vs. Uruguay, a que se refiere el presente voto razonado.

133 Punto Declarativo 2 y Considerandos 54, 55, 56, 57, 90 y 103 de la Resolución de la Corte Interamericana de 20 de marzo de 2013, relativa a la supervisión de cumplimiento de sentencia del Caso Gelman Vs. Uruguay, a que se refiere el presente voto razonado.

134 Cfr. Caso Gelman Vs. Uruguay. Fondo y Reparaciones. Sentencia de 24 de febrero de 2011. Serie C No 221, párrs. 99, 183, 225 y 254.

135 Cfr. Caso Gelman Vs. Uruguay. Fondo y Reparaciones. Sentencia de 24 de febrero de 2011. Serie C No 221, párrs. 71, 72, 73, 78, 233, 236 y 240. 
del delito de desaparición forzada de personas, la nueva ley resulta aplicable, sin que ello represente su aplicación retroactiva"; 136

(vii) que la desaparición forzada de María Macarena Gelman García Iruretagoyena, resulta como consecuencia de la sustracción, supresión y sustitución de su identidad, ${ }^{137} \mathrm{y}$

(viii) que el deber de "garantizar" que la Ley de Caducidad no vuelva a representar un obstáculo para la investigación de los hechos, juzgamiento y eventual sanción de las violaciones graves a derechos humanos, se refiere no sólo a los responsables de las víctimas del Caso Gelman, sino también de otras graves violaciones de derechos humanos similares acontecidas en Uruguay en el mismo período. ${ }^{138}$

88. El adecuado ejercicio del control de convencionalidad por las autoridades uruguayas resulta fundamental para el debido e integral cumplimiento de la Sentencia en el Caso Gelman y no puede quedar supeditado a la interpretación constitucional que realice un órgano nacional, ni siquiera invocando una norma constitucional o el ejercicio propio de su competencia al ejercer "control de constitucionalidad". Lo anterior, debido al carácter vinculante que tienen las sentencias de la Corte IDH en los términos del artículo 68.1 y de las reglas previstas en los artículos $26^{139}$ y $27^{140}$ de la Convención de Viena sobre el Derecho de los Tratados.

89. Los principios de derecho internacional público de buena fe y effet utile, que involucra a su vez al principio pacta sunt servanda, constituyen fundamentos internacionales para que los tratados internacionales sean cumplidos por parte de los Estados nacionales y han sido reiterados de manera constante por la jurisprudencia del Tribunal Interamericano. La obligación del cumplimiento

136 Caso Gelman Vs. Uruguay. Fondo y Reparaciones. Sentencia de 24 de febrero de 2011. Serie C No 221, párr. 236.

137 Cfr. Caso Gelman Vs. Uruguay. Fondo y Reparaciones. Sentencia de 24 de febrero de 2011. Serie C No 221, párrs. 60, 120, 13, 163, 230, 235 y 252.

138 Caso Gelman Vs. Uruguay. Fondo y Reparaciones. Sentencia de 24 de febrero de 2011. Serie C No 221, párrs. 232 y 253.

139 "Art. 26: Pacta sunt servanda. Todo tratado en vigor obliga a las partes y debe ser cumplido por ellas de buena fe".

140 "Art. 27. El derecho interno y la observancia de los tratados. Una parte no podrá invocar las disposiciones de su derecho interno como justificación del incumplimiento de un tratado. Esta norma se entenderá sin perjuicio de lo dispuesto en el artículo 46". 
del derecho convencional obliga a todas las autoridades y órganos nacionales, toda vez que el Estado responde en su conjunto y adquiere responsabilidad internacional ante el incumplimiento de los instrumentos internacionales que ha asumido.

90. Eso implica que derivado del Caso Gelman, todas las autoridades uruguayas (incluyendo los órganos de administración de justicia y jueces en todos los niveles) quedan vinculadas directamente por la sentencia internacional, que ha adquirido la autoridad de cosa juzgada en los términos analizados (véase supra párrs. 26 a 30). En consecuencia, todas las autoridades uruguayas deben, dentro de sus respectivas competencias, cumplir y aplicar de manera "directa" lo establecido expresamente en los puntos Declarativos 2 y 3 de la Resolución de 20 de marzo de 2013 relativa a la supervisión de cumplimiento de Sentencia a que se refiere el presente voto razonado; así como con los puntos Resolutivos 9, 10, 11, 15 y 16 de la Sentencia del Caso Gelman Vs. Uruguay de 24 de febrero de 2011, sobre los aspectos pendientes de cumplimiento, teniendo en cuenta, además, la parte considerativa que fundamenta dichos resolutivos. En este sentido, la obligación de ejercer adecuadamente "control de convencionalidad" en este caso donde existe cosa juzgada internacional resulta esencial para el debido cumplimiento de la Sentencia interamericana.

\section{B) Res interpretata y "control de convencionalidad"}

91. En cambio, la segunda manifestación del ejercicio del "control de convencionalidad" en sede nacional, se produce aplicando la jurisprudencia interamericana derivada del presente caso -incluyendo la de su cumplimiento- por los demás Estados Parte del Pacto de San José. En este sentido, adquiere eficacia interpretativa la norma convencional hacia los demás Estados Parte de la Convención Americana (res interpretata). La eficacia vinculante de la "norma convencional interpretada" -como explícitamente se advierte de los considerandos 67, 69 y 72 de la presente Resolución de cumplimiento a que se refiere el presento voto razonado-constituye una obligación convencional derivada de los artículos $1^{\circ} \mathrm{y}$ $2^{\circ}$ de la Convención Americana en los términos previamente analizados (véase supra párrs. 43 a 66).

92. La Corte IDH consideró en la Resolución de supervisión de cumplimiento a que se refiere el presente voto razonado, que el "control de convencionalidad" constituye "una obligación" de toda autoridad de los Estados Parte de la Convención de garantizar el respeto y garantía de los derechos humanos, 
dentro de las competencias y regulaciones procesales correspondientes. ${ }^{141}$ En este sentido, el fundamento de esta obligación deriva de la eficacia jurídica de la propia Convención, fundamentalmente de las obligaciones convencionales de "respeto", "garantía" y "adecuación" (normativa/intrepretativa) previstas en los artículos $1^{\circ}$ y $2^{\circ}$ del Pacto de San José, en relación con el artículo 29 del mismo Pacto, con la finalidad de lograr la mayor efectividad del derecho humano involucrado.

93. Así, la segunda manifestación del ejercicio del "control de convencionalidad", en situaciones y casos en que el Estado concernido no ha sido parte en el proceso internacional en que fue establecida determinada jurisprudencia, por el solo hecho de ser Parte en la Convención Americana, toda autoridad pública y todos sus órganos, incluidas las instancias democráticas ${ }^{142}$, jueces y demás órganos vinculados a la administración de justicia en todos los niveles, están obligados por el tratado, lo cual les obliga a ejercer ex officio un control de convencionalidad, teniendo en cuenta el propio tratado y la interpretación que del mismo ha realizado la Corte Interamericana, en el marco de sus respectivas competencias y de las regulaciones procesales correspondientes, sea "en la emisión y aplicación de normas, en cuanto a su validez y compatibilidad con la Convención, como en la determinación, juzgamiento y resolución de situaciones particulares y casos concretos". 143

141 Considerando 72 de la Resolución de supervisión de cumplimiento de Sentencia en el Caso Gelman $V$ s. Uruguay, a que se refiere el presente voto razonado.

142 "La legitimación democrática de determinados hechos o actos en una sociedad está limitada por las normas y obligaciones internacionales de protección de los derechos humanos reconocidos en tratados como la Convención Americana, de modo que la existencia de un verdadero régimen democrático está determinada por sus características tanto formales como sustanciales, por lo que, particularmente en casos de graves violaciones a las normas del Derecho Internacional de los Derechos, la protección de los derechos humanos constituye un límite infranqueable a la regla de mayorías, es decir, a la esfera de lo 'susceptible de ser decidido' por parte de las mayorías en instancias democráticas, en las cuales también debe primar un control de convencionalidad, que es función y tarea de cualquier autoridad pública y no sólo del Poder Judicial. En este sentido, la Suprema Corte de Justicia ha ejercido, en el Caso Nibia Sabalsagaray Curutchet, un adecuado control de convencionalidad respecto de la Ley de Caducidad, al establecer, inter alia, que 'el límite de la decisión de la mayoría reside, esencialmente, en dos cosas: la tutela de los derechos fundamentales (los primeros, entre todos, son el derecho a la vida y a la libertad personal, y no hay voluntad de la mayoría, ni interés general ni bien común o público en aras de los cuales puedan ser sacrificados) y la sujeción de los poderes públicos a la ley'. Otros tribunales nacionales se han ido también a los límites de la democracia en relación con la protección de derechos fundamentales" (Sentencia del Caso Gelman Vs. Uruguay, párr. 239).

143 Considerando 69 de la Resolución de supervisión de cumplimiento de Sentencia en el Caso Gelman

Vs. Uruguay, a que se refiere el presente voto razonado. 
94. La eficacia interpretativa de la norma convencional interamericana resulta relativa, en la medida en que en todo caso las autoridades nacionales podrán efectivizar la norma convencional mediante una interpretación más favorable de conformidad con el principio pro personae que establece el artículo 29 del Pacto de San José (véase supra párrs. 52 a 55).

95. No debe pasar inadvertido que la Corte IDH se ha pronunciado con anterioridad sobre la incompatibilidad a la Convención Americana respecto de leyes de amnistía o auto amnistía que involucran la responsabilidad internacional de otros Estados en particular. ${ }^{144}$ En esos supuestos concretos, evidentemente, estamos en la primera manifestación del "control de convencionalidad" al vincular directamente la sentencia interamericana a las partes que intervinieron en el proceso internacional, al adquirir el fallo la autoridad de la cosa juzgada.

96. Además, en más de veinte casos contenciosos el Tribunal Interamericano se ha pronunciado sobre diversos aspectos del "control de convencionalidad" en sentencias que involucran la responsabilidad internacional de trece Estados distintos: Argentina, ${ }^{145}$ Barbados, ${ }^{146}$ Boliva, ${ }^{147}$ Brasil, ${ }^{148}$ Chile, ${ }^{149}$ Colombia, ${ }^{150}$

144 Caso Barrios Altos Vs. Perú. Fondo. Sentencia de 14 de marzo de 2001. Serie C, No 75; Caso Almonacid Arellano y otros Vs. Chile. Excepciones Preliminares, Fondo, Reparaciones y Costas. Sentencia de 26 de septiembre de 2006. Serie C, No 154; Caso La Cantuta Vs. Perú. Fondo, Reparaciones y Costas. Sentencia de 29 de noviembre de 2006. Serie C, No 162; Caso Gomes Lund y otros (Guerrilha do Araguaia) Vs. Brasil. Excepciones Preliminares, Fondo, Reparaciones y Costas. Sentencia de 24 de noviembre de 2010, Serie C, No 219; Caso Gelman Vs. Uruguay. Fondo y Reparaciones. Sentencia de 24 de febrero de 2011 Serie C, No 221; y Caso Masacres de El Mozote y lugares aledaños Vs. El Salvador. Fondo, Reparaciones y Costas. Sentencia de 25 de octubre de 2012 Serie C, No 252.

145 Caso Fontevecchia y D'Amico Vs. Argentina. Fondo, reparaciones y costas. Sentencia de 29 de noviembre de 2011. Serie C No 238, párrs. 93, 94 y 113; y Caso Furlan y Familiares Vs. Argentina. Excepciones Preliminares, Fondo, Reparaciones y Costas. Sentencia de 31 de agosto de 2012 Serie C No 246, párrs. 303 a 305.

146 Caso Boyce y otros Vs. Barbados. Excepción Preliminar, Fondo, Reparaciones y Costas. Sentencia de 20 de noviembre de 2007. Serie C No 169, párr. 79.

147 Caso Ibsen Cárdenas e Ibsen Peña Vs. Bolivia. Fondo, Reparaciones y Costas. Sentencia de $1^{\circ}$ de septiembre de 2010. Serie C No 217, párr. 202.

148 Caso Gomes Lundy Otros (Guerrilha do Araguaia) Vs. Brasil. Excepciones preliminares, fondo, reparaciones y costas. Sentencia de 24 de noviembre de 2010. Serie C No 219, párrs. 49 y 106.

149 Caso Almonacid Arellano y otros Vs. Chile. Excepciones Preliminares, Fondo, Reparaciones y costas. Sentencia de 26 de septiembre de 2006. Serie C No 154, párr. 124; y Caso Atala Riffo y Niñas vs. Chile. Fondo, reparaciones y costas. Sentencia de 24 de febrero de 2012. Serie C No 239, párrs. 282 a 284.

150 Caso Manuel Cepeda Vargas vs. Colombia. Excepciones Preliminares, Fondo y Reparaciones. Sentencia de 26 de mayo de 2010. Serie C No 213, párr. 208, nota al pie 307; y Caso Masacre de Santo Domingo Vs. Colombia. Excepciones Preliminares, Fondo y Reparaciones. Sentencia de 30 de noviembre de 2012 Serie C No 259, párrs. 142 a 144. 
Guatemala, ${ }^{151}$ México, ${ }^{152}$ Panamá, 153 Paraguay, ${ }^{154}$ Perú, 155 Uruguay156 y Venezuela; ${ }^{157}$ lo que significa más de la mitad de los Estados Parte de la Convención que han reconocido la jurisdicción contenciosa de la Corte IDH. Desde el Caso Cabrera García y Montiel Flores Vs. México de 2010,158 la Corte IDH ha venido ejemplificando la manera en que tribunales de la más alta jerarquía en varios Estados de la región se refieren al carácter vinculante de las sentencias del Tribunal Interamericano y la manera en que han recibido o aplicado el control de convencionalidad teniendo en consideración la jurisprudencia interamericana, como ahora se realiza en la presente Resolución de supervisión de cumplimiento de sentencia, a que se refiere el presente voto razonado, citando los casos de Argentina, Bolivia, Colombia, Costa Rica, Guatemala, México, Panamá, Perú y República Dominicana. ${ }^{159}$ Asimismo, el propio Tribunal Interamericano retoma

151 Caso Masacres de Río Negro Vs. Guatemala. Excepción Preliminar, Fondo, Reparaciones y Costas. Sentencia de 4 de septiembre de 2012 Serie C No 250, párr. 262; y Caso Gudiel Álvarez y otros ("Diario Militar") Vs. Guatemala. Fondo Reparaciones y Costas. Sentencia de 20 noviembre de 2012 Serie C No 253, párr. 330.

152 Caso Rosendo Radilla Pacheco Vs. Estados Unidos Mexicanos. Excepciones Preliminares, Fondo, Reparaciones y Costas. Sentencia de 23 de noviembre de 2009. Serie C No 209, párr. 339 y nota al pie 321; Caso Fernández Ortega y Otros Vs. México. Excepción Preliminar, Fondo, Reparaciones y Costas. Sentencia de 30 de agosto de 2010. Serie C No 215, párrs. 236 y 237; Caso Rosendo Cantú y Otra vs. México. Excepción Preliminar, Fondo, Reparaciones y Costas. Sentencia de 31 de agosto de 2010. Serie C No 216, párrs. 219 y 220; y Caso Cabrera García y Montiel Flores Vs. México. Excepciones Preliminares, Fondo, Reparaciones y Costas. Sentencia de 26 de noviembre de 2010. Serie C No 220, párrs. 21 y 225 a 233.

153 Caso Heliodoro Portugal vs. Panamá. Excepciones Preliminares, Fondo, Reparaciones y Costas. Sentencia de 12 de agosto de 2008. Serie C No 186, párr. 180; y Caso Vélez Loor vs. Panamá. Excepciones preliminares, fondo, reparaciones y costas. Sentencia de 23 de noviembre de 2010. Serie C No 218, párr. 287.

154 Comunidad Indígena Xákmok Kásek Vs. Paraguay. Fondo, Reparaciones y Costas. Sentencia de 24 de agosto de 2010. Serie C No 214, párr. 311.

155 Caso Trabajadores Cesados del Congreso (Aguado Alfaro y otros) vs. Perú. Excepciones Preliminares, Fondo, Reparaciones y Costas. Sentencia de 24 de noviembre de 2006. Serie C No 158, párr. 128; Caso La Cantuta vs. Perú. Fondo, Reparaciones y Costas. Sentencia de 29 de noviembre de 2006. Serie C No 162, párr. 173.

156 Caso Gelman Vs. Uruguay. Fondo y Reparaciones. Sentencia de 24 de febrero de 2011. Serie C No 221, párrs. 193 y 239.

157 Caso Chocrón Chocrón Vs. Venezuela. Excepciones preliminares, fondo, reparaciones y costas. Sentencia de $1^{\circ}$ de julio de 2011. Serie C No 227, parrs. 164, 165 y 172; y Caso López Mendoza Vs. Venezuela. Fondo Reparaciones y Costas. Sentencia de 1 de septiembre de 2011. Serie C No 233, párrs. 226 a 28.

158 Cfr. Caso Cabrera García y Montiel Flores Vs. México. Excepción Preliminar, Fondo, Reparaciones y Costas. Sentencia de 26 de noviembre de 2010. Serie C No 220, párrs. 226 a 232.

159 Considerandos 74 a 86 de la Resolución de supervisión de cumplimiento de Sentencia en el Caso Gelman Vs. Uruguay, a que se refiere el presente voto razonado. 
jurisprudencia nacional para fundamentar y conceptualizar en sus resoluciones la violación de la Convención Americana. ${ }^{160}$

97. La Sentencia del Caso Gelman Vs. Uruguay de 24 de febrero de 2011, constituye un precedente de la mayor importancia para el Sistema Interamericano y en el carácter evolutivo de la jurisprudencia interamericana sobre la doctrina del "control de convencionalidad", toda vez que con claridad explicitó que este tipo de control debe realizarse ex officio por todas las autoridades nacionales -incluyendo las instancias democráticas- "en las cuales también debe primar un 'control de convencionalidad', que es función y tarea de cualquier autoridad pública y no sólo del Poder Judicial". ${ }^{161}$ En esta misma línea se estableció en el Caso Masacre de Santo Domingo Vs. Colombia de noviembre de 2012, que todas las autoridades y órganos de un Estado Parte en la Convención tienen la obligación de ejercer un "control de convencionalidad". 162

98. Así, se ha generado un "control dinámico y complementario" de las obligaciones convencionales de los Estados de respetar y garantizar derechos humanos, conjuntamente entre las autoridades nacionales (que tienen la obligación primaria y fundamental en la garantía de los derechos y de ejercer "control de convencionalidad") y las instancias internacionales -en forma subsidiaria y complementaria; ${ }^{163}$ de modo que los criterios de decisión pueden ser conformados y adecuados

160 Considerando 71 de la Resolución de supervisión de cumplimiento de Sentencia en el Caso Gelman

Vs. Uruguay, a que se refiere el presente voto razonado.

161 Caso Gelman Vs. Uruguay. Fondo y Reparaciones. Sentencia de 24 de febrero de 2011. Serie C No 221, párrs. 193 y 239.

162 Caso Masacre de Santo Domingo Vs. Colombia. Excepciones Preliminares, Fondo y Reparaciones. Sentencia de 30 de noviembre de 2012 Serie C No 259, párr. 142.

163 Cfr. Caso Masacre de Santo Domingo Vs. Colombia. Excepciones Preliminares, Fondo y Reparaciones. Sentencia de 30 de noviembre de 2012 Serie C No 259. En el Considerando 142 se expresa: La responsabilidad estatal bajo la Convención sólo puede ser exigida a nivel internacional después de que el Estado haya tenido la oportunidad de declarar la violación y reparar el daño ocasionado por sus propios medios. Esto se asienta en el principio de complementariedad (subsidiariedad), que informa transversalmente el Sistema Interamericano de Derechos Humanos, el cual es, tal como lo expresa el Preámbulo de la misma Convención Americana, "coadyuvante o complementario de la [protección] que ofrece el derecho interno de los Estados americanos". De tal manera, el Estado "es el principal garante de los derechos humanos de la personas, de manera que, si se produce un acto violatorio de dichos derechos, es el propio Estado quien tiene el deber de resolver el asunto a nivel interno y, [en su caso,] reparar, antes de tener que responder ante instancias internacionales como el Sistema Interamericano, lo cual deriva del carácter subsidiario que reviste el proceso internacional frente a los sistemas nacionales de garantías de los derechos humanos". Esas ideas también han adquirido forma en la jurisprudencia reciente bajo la concepción de que todas las autoridades y órganos de un Estado Parte en la Convención tienen la obligación de ejercer un "control de convencionalidad". (Cursivas nuestras). 